\title{
5. PHYSIOGRAPHY AND STRUCTURE OF THE WESTERN IBERIAN CONTINENTAL MARGIN OFF GALICIA, FROM SEA BEAM AND SEISMIC DATA
}

\author{
Jean-Claude Sibuet, ${ }^{1}$ Jean-Pierre Mazé, ${ }^{1}$ \\ Philip Amortila, ${ }^{1,2}$ and Xavier Le Pichon ${ }^{3}$
}

\begin{abstract}
A new bathymetric map, based on Sea Beam data, was compiled for the continental margin south of Galicia Bank, in the area of Ocean Drilling Program (ODP) Leg 103 drilling. Using a new series of 12 single-channel seismic profiles oriented perpendicularly to the continental margin and multichannel seismic profiles previously acquired in the area, we constructed a detailed map of the surface of the tilted fault blocks and half grabens formed during the Early Cretaceous phases of rifting. Tilted fault blocks 13-18 km apart and oriented roughly north-south, are continuous over distances of as great as $60 \mathrm{~km}$. We divided the upper and lower parts of the margin on the basis of magnetic data, distance between tilted fault blocks, nature of sediments involved in the rifting processes (pre- and syn-rift or only syn-rift sediments). This report also discusses the significance of the $\mathrm{S}$ reflector located below the tilted fault blocks.
\end{abstract}

\section{INTRODUCTION}

In early 1982 , the Seagal cruise was conducted by IFREMER (Institut Français de Recherche pour l'Exploitation de la Mer) on the Jean Charcot to collect Sea Beam and single-channel seismic-reflection data to investigate the early geologic history of rifting, subsidence, and sedimentation of the western Galicia continental margin. With two 90 -in. ${ }^{3}$ water guns and four 540 in. ${ }^{3}$ air guns, $1800 \mathrm{~km}$ of seismic data were acquired. Sea Beam coverage was designed to avoid any ambiguity concerning lateral extension or correlation of morphologic features between profiles over the entire surveyed area (Fig. 1). Because the post-rift sedimentary cover is thin, most of the basement-rock features have bathymetric expression, and their trends are clearly established by Sea Beam data.

In this chapter, we present a new bathymetric map based on these Sea Beam data. This map has been integrated into the general bathymetric map of the northeast Atlantic Ocean, recently published by Lallemand et al. (1985a and b) (Fig. 1). The data are examined in the context of preliminary drilling results of ODP Leg 103 (Boillot, Winterer, et al., 1985, 1986; see site chapters, this volume). We also discuss these data within a geological framework, which indicates that the western Iberian continental margin was formed in an area previously affected by the late Hercynian orogeny and subsequent tensional phases (Fig. 2).

\section{METHODS}

\section{Sea Beam Data Processing}

The new bathymetric map of southwest Galicia margin presented in this paper was compiled exclusively from Sea Beam data. Basic data are those of the Seagal cruise, but all available Sea Beam transits acquired in the area have been used. The Sea Beam system is a multibeam echo-sounder, comprising 16 adjacent narrow beams. Width of the mapped swath beneath the track is approximately two-thirds of the water depth (Renard

\footnotetext{
${ }^{1}$ IFREMER Centre de Brest, B.P. 337, 29273 Brest cédex, France.

2 Now at Geophysical Company of Norway (U.K.), The GECO Centre, Knoll Rise, Orpington, Kent BR6 OXG, England.

${ }_{3}^{3}$ Ecole Normale Supérieure, Département de Géologie, 24, rue Lhomond, 75231 Paris cédex 05, France.
}

and Allenou, 1979). The track control of Sea Beam data used to compile the bathymetric map is shown in Figure 3.

During the Seagal cruise, twelve $\mathrm{N} 95^{\circ} \mathrm{E}$ parallel profiles, each about $150 \mathrm{~km}$ long, were acquired perpendicular to the trend of the tilted fault blocks formed during the Early Cretaceous rifting episode. Profile spacing was $5.5 \mathrm{~km}$. Sea Beam transverse profiles are important because they cut the Seagal $\mathrm{N} 95^{\circ} \mathrm{E}$ profiles and provide improved navigation through bathymetric constraints. The REGINA (Recalage Graphique Interactif de la Navigation à partir du Sea Beam) software package developed by IFREMER allowed us to fit the Sea Beam bathymetric contours of two crossing lines by moving one line with respect to another. This was done on a color screen in a normal or automatic mode. If the bathymetry was not flat, each crossing gave a navigation constraint (i.e., two points corresponding to the same position). Then, this new set of Sea Beam navigation constraints was merged with the conventional navigation data set to provide a new navigation data set. The transit satellite navigation was consequently improved, and distortions owing to automatic contouring procedures were avoided near crossings. Several types of interpolation procedures could be used to create a regular grid. The size of the grid net and the smoothing rate of Sea Beam data were chosen as a function of both the navigation accuracy and the Sea Beam coverage. The resulting bathymetric contour map appears in Figure 4. The Sea Beam coverage is about $50 \%$ in the western part of the study area but only about $30 \%$ in the upper part of the margin to the east. The accuracy of the bathymetric map consequently diminishes slightly eastward. Depths are in uncorrected meters (assuming a water velocity of $1500 \mathrm{~m} / \mathrm{s}$ ), and the bathymetric contour interval is $50 \mathrm{~m}$. Detailed maps having $10-\mathrm{m}$ isobath spacing are shown near ODP Leg 103 sites.

A three-dimensional bathymetric diagram was also constructed (Fig. 5; see frontispiece, this volume), presenting a viewpoint, vertical exaggeration, and smoothing rate that give the best exhibition of the Galicia margin morphologic trends.

\section{Seismic-Refraction and -Reflection Velocities}

Three seismic-refraction profiles using sonobuoys were acquired in the abyssal domain during the Seagal cruise (location in Fig. 3). The seismic source was four 940 -in. ${ }^{3}$ air guns towed $10 \mathrm{~m}$ below sea surface at a speed of $6 \mathrm{kt}$. Shots were spaced every $25 \mathrm{~s}$. Velocities and thicknesses were calculated from both wide-angle reflection and refraction arrivals (Le Pichon et al., 


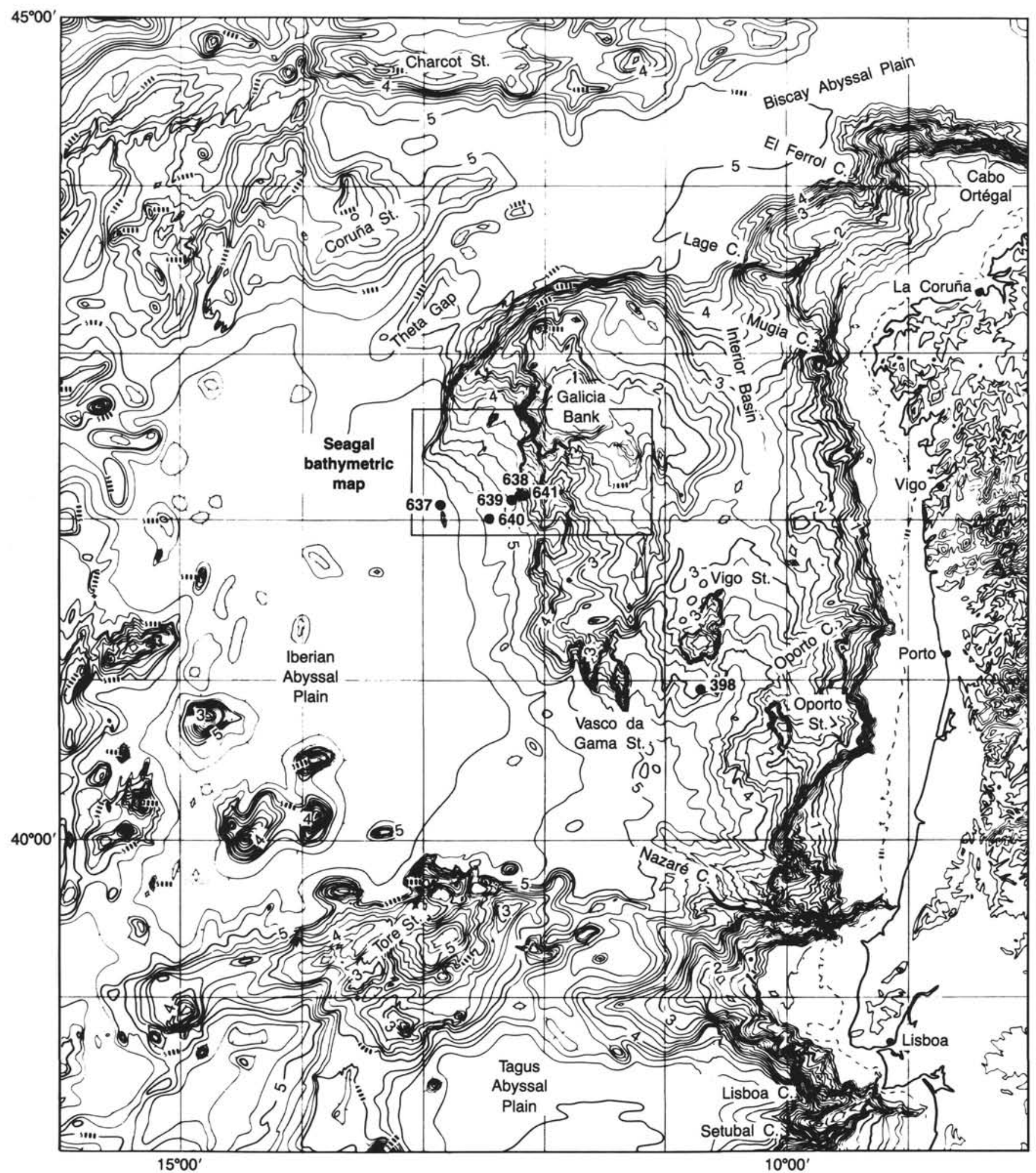

Figure 1. Bathymetric map of the Galicia Bank area (after Lallemand et al., 1985a and b). Contour spacing $200 \mathrm{~m}$; for ease of identification, contours are labeled in both meters (smaller numbers) and kilometers (larger numbers). ODP sites are located within the box showing the limits of the Seagal bathymetric map.

1968). Table 1 lists sonobuoy refraction and reflection velocities based on the assumption of a surface-sound-channel velocity of $1.51 \mathrm{~km} / \mathrm{s}$. Because the refraction profiles were not reversed and were shot perpendicularly to the basement features, velocities determined for the tilted fault blocks and the lower crust are not precise. Nevertheless, these results are consistent with the compressional wave velocities (Fig. 6) obtained by the Dix relation from root mean square (rms) velocity spectra after processing the multichannel seismic profile GP-08 located near the refraction profiles (Groupe Galice, 1979; Fig. 3). 


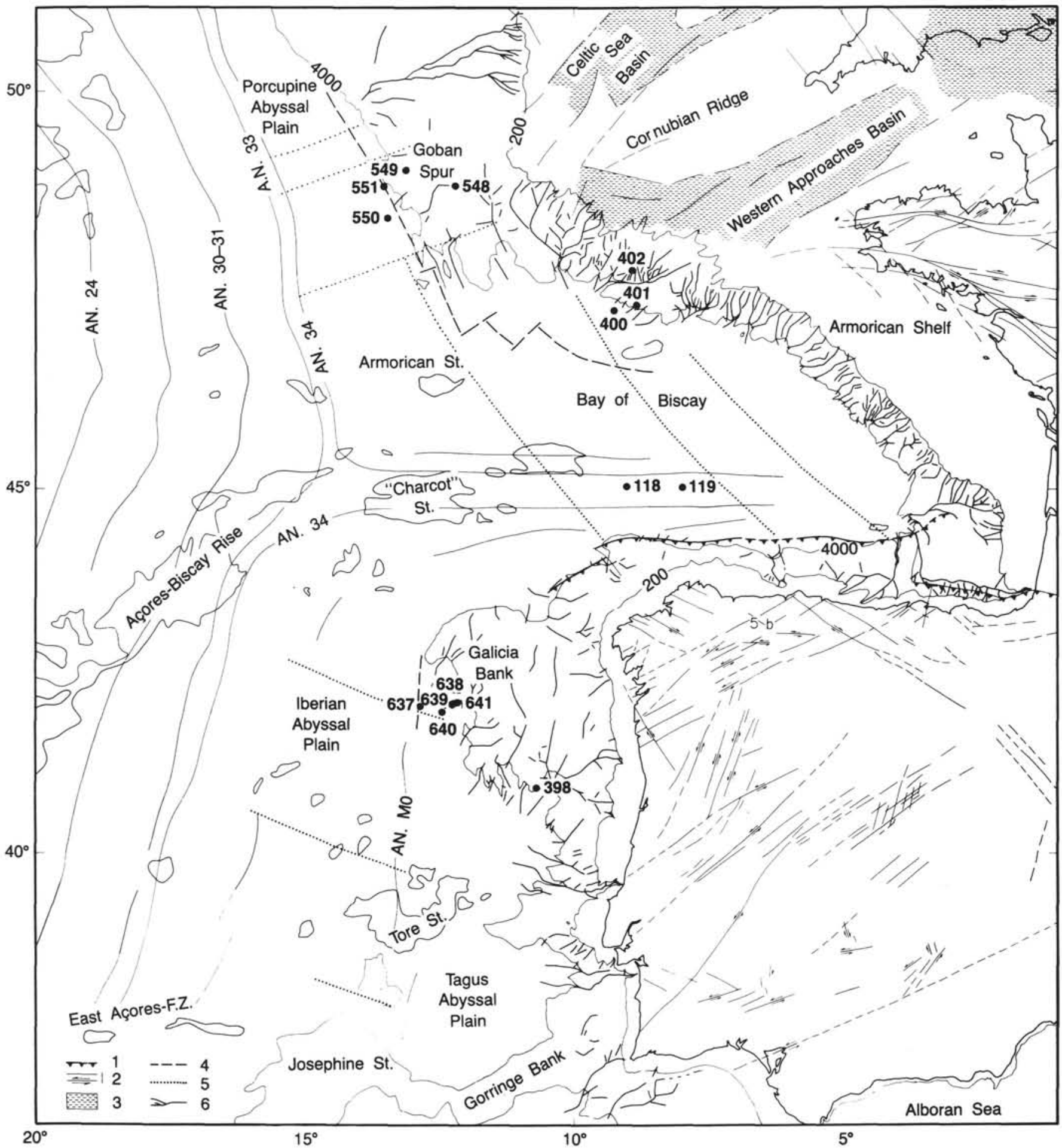

Figure 2. General structural map of the northeast Atlantic, showing identified magnetic anomalies (Guennoc et al., 1978, 1979; Sibuet and Ryan, 1979a; Verhoef et al., 1986). Canyon trends are shown on the continental margins (Lallemand and Sibuet, in press): (1) north Iberian Paleogene thrusting front; (2) late Hercynian faults on land and continental shelves, after Parga (1969), Arthaud and Matte (1975), Montadert et al. (1979d), and Sibuet et al. (1985); (3) approximate present limit of Jurassic sediments in the Western Approaches and Celtic Sea Basins (Pegrum and Mountenay, 1978); (4) continent/ocean boundary (Sibuet et al., 1985); (5) flow lines of initial opening of Bay of Biscay and northeast Atlantic Ocean (Olivet et al., 1984; Savostin et al., 1986); (6) directions of canyon orientations on the continental margins (Lallemand and Sibuet, in press). 


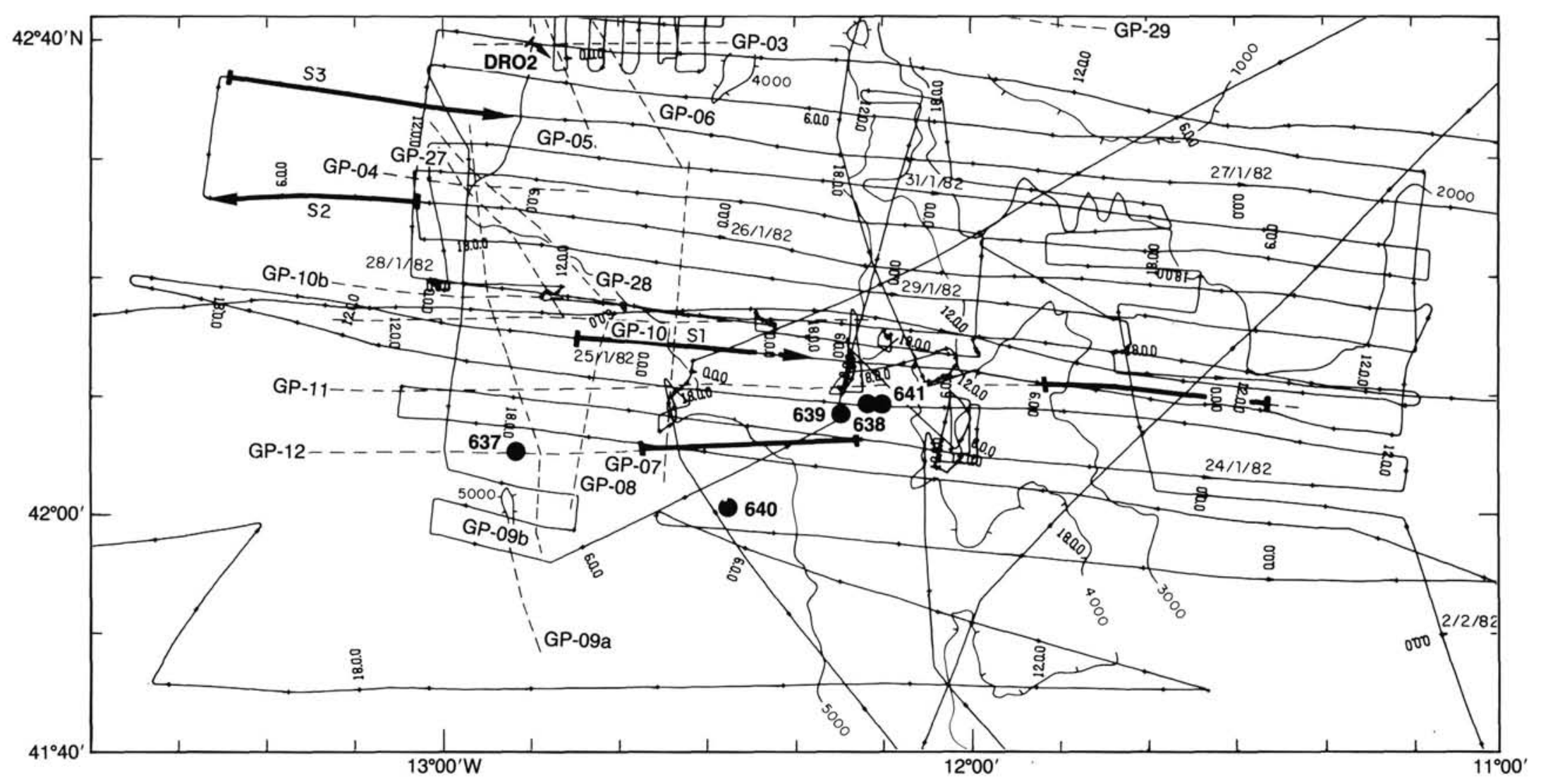

Figure 3. Location map of the Sea Beam and single-channel seismic profiles acquired during the Seagal cruise (continuous lines) and IFP-CNEXO multichannel seismic profiles (dashed lines). Location of refraction sonobuoys S1, S2, and S3 and the parts of multichannel lines GP-11 and GP-12 shown in Figure 10 are indicated. Location of sites drilled during ODP Leg 103 are also shown. 


$$
\begin{aligned}
& 7 \text { Snरें } \\
& -1.3 \\
& \hline
\end{aligned}
$$




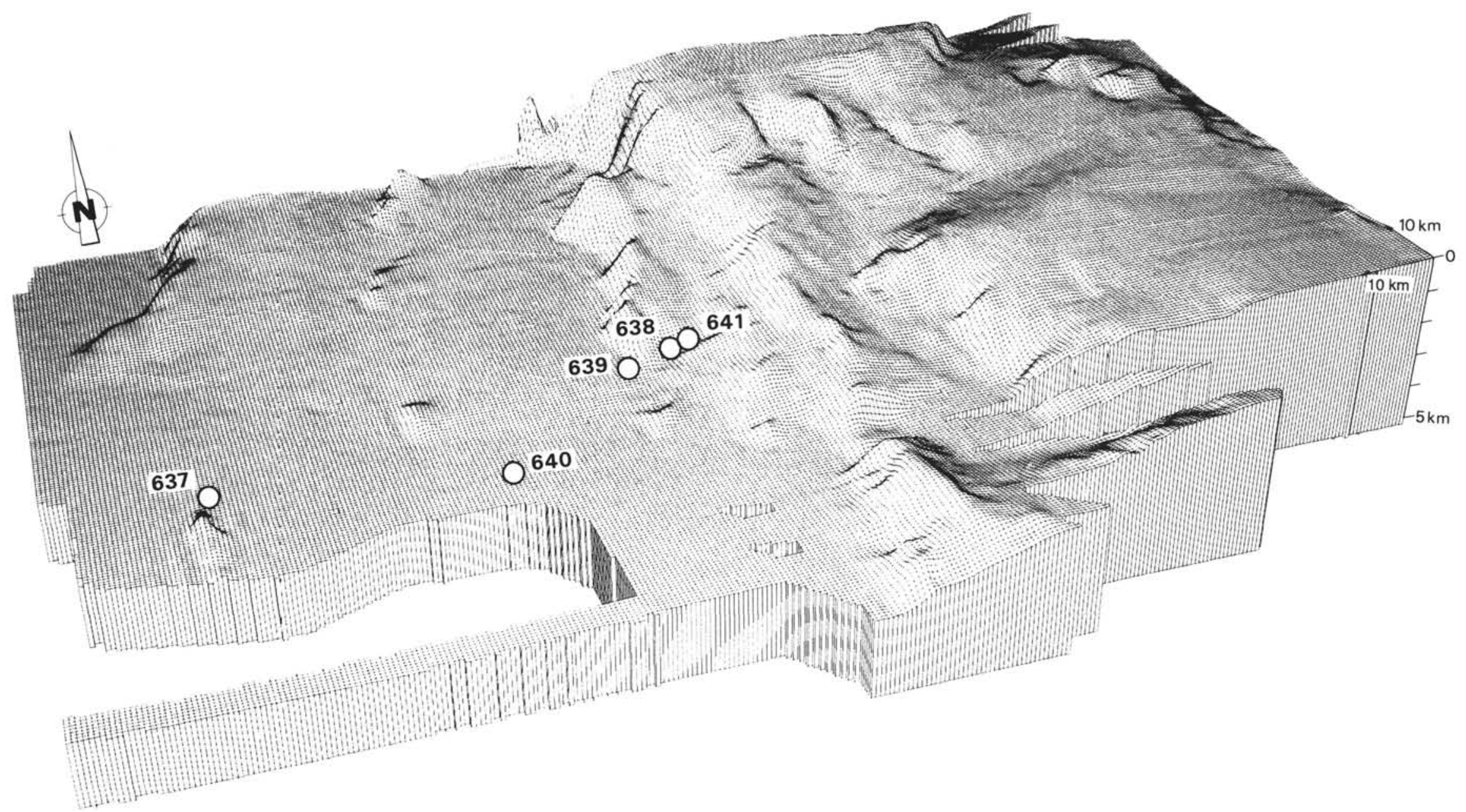

Figure 5. Block diagram showing the bathymetry of southwest Galicia margin. Vertical exaggeration, $\times 5$. Grid dimension, $500 \mathrm{~m}$. Point of view was chosen to highlight the north-south basement structures. Diagram provided by G. Riou and A. Normand of the IFREMER ATDO (Assistance et Traitement des Données Océaniques). See frontispiece (this volume) for a color version of this diagram. 
Table 1. Refraction and wide-angle reflection results from sonobuoy data.

\begin{tabular}{|c|c|c|c|c|c|c|c|c|c|c|c|c|c|c|c|}
\hline \multirow{2}{*}{$\begin{array}{c}\text { Refraction } \\
\text { profile }\end{array}$} & \multicolumn{2}{|c|}{$\begin{array}{l}\text { Position of the } \\
\text { ends of profiles }\end{array}$} & \multicolumn{7}{|c|}{ Velocity of layers (in $\mathrm{km} / \mathrm{s}$ ) } & \multicolumn{6}{|c|}{ Thickness of layers (in km) } \\
\hline & Latitude & Longitude & Water & A & B & C & D & E & $\mathrm{F}$ & Water & A & B & C & D & $\mathrm{E}$ \\
\hline S1 & $\begin{array}{l}42^{\circ} 15^{\prime} \mathrm{N} \\
42^{\circ} 13^{\prime} \mathrm{N}\end{array}$ & $\begin{array}{l}12^{\circ} 46^{\prime} \mathrm{W} \\
12^{\circ} 19^{\prime} \mathrm{W}\end{array}$ & 1.51 & 2.05 & 2.55 & 2.9 & 4.33 & 6.1 & 8.01 & 5.175 & 0.595 & 1.02 & 0.373 & 0.97 & 1.47 \\
\hline S2 & $\begin{array}{l}42^{\circ} 26^{\prime} \mathrm{N} \\
42^{\circ} 27^{\prime} \mathrm{N}\end{array}$ & $\begin{array}{l}13^{\circ} 03^{\prime} \mathrm{W} \\
13^{\circ} 27^{\prime} \mathrm{W}\end{array}$ & 1.51 & & & 3.12 & 4.2 & 5.87 & 7.8 & 5.287 & 1.1 & & 0.5 & 1.06 & 0.93 \\
\hline S3 & $\begin{array}{l}42^{\circ} 37^{\prime} \mathrm{N} \\
42^{\circ} 34^{\prime} \mathrm{N}\end{array}$ & $\begin{array}{l}13^{\circ} 24^{\prime} \mathrm{W} \\
12^{\circ} 53^{\prime} \mathrm{W}\end{array}$ & 1.51 & & & 3.14 & 4.3 & 5.8 & - & 5.280 & 1.6 & & 1.1 & 0.31 & - \\
\hline
\end{tabular}

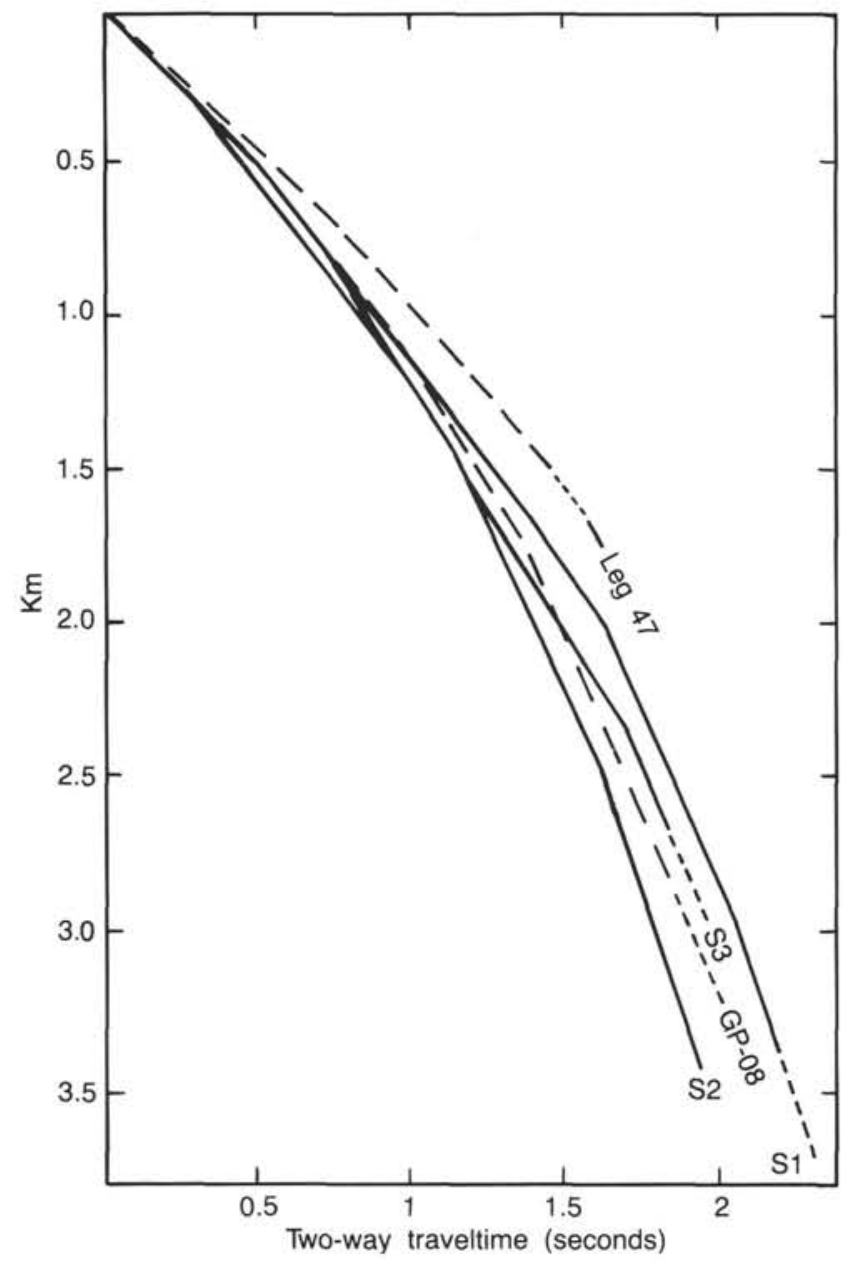

Figure 6. Results of the three sonobuoy profiles listed in Table 1, compared with velocities calculated from multichannel seismic profile GP08 (Groupe Galice, 1979) and Leg 47B results (Sibuet, Ryan, et al., 1979b).

Results of the velocity-depth correlation at Site 398 (Sibuet, Ryan et al., 1979a) are also reported. A fair agreement exists between the different data. We adopted the velocity-depth profile of Figure 7 to compute the thickness of the post-rift sediment layers and to deduce the depth of sediments affected by rifting for the entire southwestern Galicia margin.

\section{REGIONAL TECTONIC SETTING}

The starved continental margin of western Galicia Bank was formed during several phases of extension since the Permian and was affected by early Tertiary and Miocene compressions.

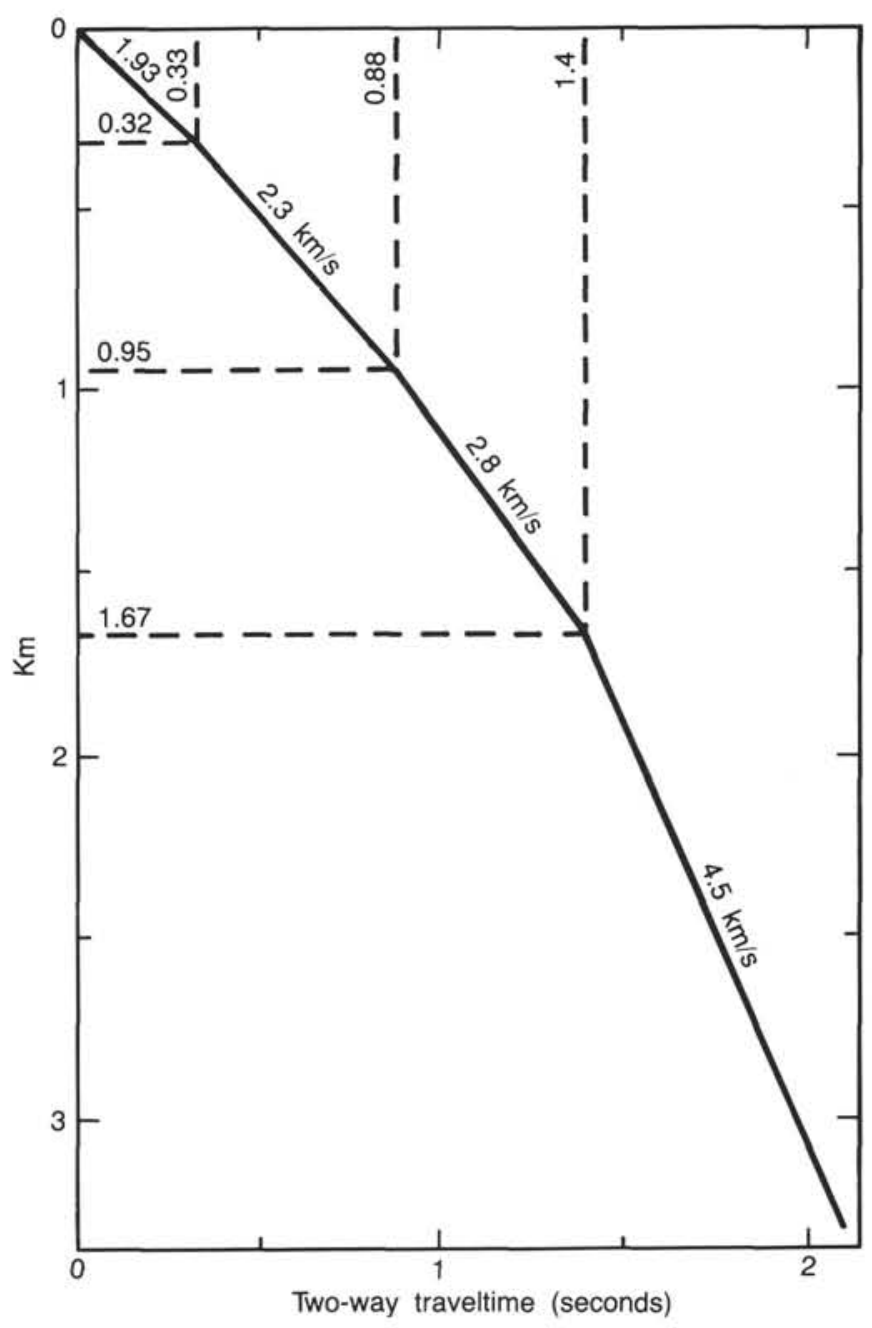

Figure 7. Depth-velocity profile adopted to compute basement depths on southwestern Galicia margin.

\section{Permian to Lias Phases of Distension}

The Permian to Triassic phase of distension documented in northwest Europe (Ziegler, 1978, 1981) and in Morocco (Manspeizer et al., 1978) is interpreted as being the first phase of doming before rifting in the western Iberian Peninsula (Mougenot et al., 1979). Extension is indicated in late Triassic-early Liassic time by the large basins occurring in Algarve (Mougenot et al., 1979) and probably in the eastern part of the Tagus Abyssal Plain (Olivet et al., 1984) where thick Liassic and Dogger sedimentary strata accumulated. 
Only during the Liassic did the large subsidence rates occur that are observed in narrow and deep basins, for example, as in Portugal. This Liassic phase of distension, which is also marked by large volcanic emissions, is associated with the first rifting phase (Mougenot et al., 1979). Sibuet and Ryan (1979) emphasized this phase in their interpretation of the subsidence history at Deep Sea Drilling Project (DSDP) Site 398 (Sibuet, Ryan et al., 1979a). During the Middle Jurassic, marine sediments deposited in Portugal (Lusitanian Basin, Mougenot et al., 1979) suggest the existence of a regional subsidence that we associate with the thermal cooling of the lithosphere after the late Triassic-Liassic phase of rifting.

\section{Latest Jurassic to Early Cretaceous Phases of Distension}

The latest Jurassic to Early Cretaceous phases of distension resulted in the formation of the present-day continental margins of the North Atlantic Ocean north of the Azores-Gibraltar fracture zone. These phases affected the entire northwest European and Arctic-North Atlantic rift system. The timing and geometry of this rifting phase have been well established both from the interpretation of seismic data and from DSDP and ODP holes drilled on the eastern North Atlantic continental margins during DSDP Legs 47B, 48, 80, 81, and ODP Leg 103 (Sibuet, Ryan, et al., 1979b; Montadert, Roberts, et al., 1979a; de Graciansky, Poag, et al., 1985; Roberts, Schnitker, et al., 1984; Boillot, Winterer, et al., 1985, 1986).

From Goban Spur to Gibraltar (Fig. 2), the overall tectonic style of continental-margin deformation is characterized by a series of tilted fault blocks bounded by normal or listric faults, which delineate half grabens. Tilted fault blocks developed within the Jurassic sedimentary cover. Western Galicia margin is the most spectacular example of this tilted fault-block geometry. One of the most important results of ODP Leg 103 was to show that the extension and deepening of the western Galicia continental margin occurred in several stages. The Jurassic carbonate platform faulted and subsided during the latest Tithonian-earliest Valanginian. Depressions were partly buried by Valanginian and Hauterivian interbedded turbidite sandstones and claystones, themselves affected until the Aptian by normal faulting and rotation of fault blocks (Boillot, Winterer, et al., 1985, 1986). Consequently, faulting and tilting began at least as early as Early Cretaceous and continued episodically until late Aptian. A comparison with the land and shelf geology shows that the latest Jurassic-Early Cretaceous phase is in fact a succession of tectonic phases, the main one being the Austrian phase (Baranyi et al., 1976; Kamerling, 1979).

\section{Onset of Seafloor Spreading}

The initiation of seafloor spreading in the northeast Atlantic is well documented in DSDP and ODP data by both dating of the first oceanic crust and dating of the regional unconformity that marks the end of the rifting phase on continental margins. The oldest oceanic magnetic anomalies identified are M0 (late Aptian) west of Galicia Bank and 34 (late Santonian) in the Bay of Biscay and west of the British Isles (Fig. 2; e.g., Guennoc et al., 1978, 1979; Sibuet and Ryan, 1979). From drilling results, the first appearance of oceanic crust was dated to be late-early Albian at Goban Spur (Masson et al., 1985), early Albian near the Meriadzek Terrace in the Bay of Biscay (Montadert et al., 1979c; Groupe Cymor, 1981), and late Aptian west and south of Galicia Bank (Sibuet and Ryan, 1979; Boillot, Winterer, et al., $1985,1986)$. This indicates that the initial formation of oceanic crust after the Late Jurassic-Early Cretaceous rifting phase propagated from south to north.

\section{Cenozoic Compressive Phases}

From Late Cretaceous to late Eocene, compressive movements resulted in uplift of the Pyrenees, the maximum tectonic activity being during the Eocene. The Pyrenees, the northern Spanish marginal trough, the Açores-Biscay Rise, and the King's Trough complex have been interpreted, according to distribution of magnetic anomalies in the North Atlantic, as features created at the plate boundary between Iberia and Europe (Le Pichon and Sibuet, 1971) and resulting from a counterclockwise rotation of Iberia with respect to Europe around a pole located west of Morocco (Olivet et al., 1984).

In the oceanic area, maximum deformation occurred near the north Iberian-European plate boundary. Numerous areas were uplifted during late Eocene, including both the oceanic domain and the continental margins (Montadert et al., 1979d; Groupe Galice, 1979; Groupe Cybère, 1984; Sibuet et al., 1985). In the Galicia Bank area, the large faults that run along the northwest edge of Galicia Bank continue to the southwest, where large deformations with clear reverse faulting affect the Mesozoic and Eocene sedimentary layers (Montadert et al., 1979d; Réhault and Mauffret, 1979; Groupe Cybère, 1984). Contemporaneous movements occurred in the Interior Basin, between $\mathrm{Ga}$ licia Bank and the continent.

Numerous studies show that deformation occurred on land in the whole continental domain of North Africa, Iberia, and Europe (de Charpal et al., 1974; Letouzey and Trémolières, 1980; Bergerat, 1985). The stress field is characterized by a northsouth horizontal compression, in agreement with the relative north-south compressive motion of Africa with respect to Europe (Savostin et al., 1986), which resulted in a transcurrent tectonic regime from northeastern Iberia to the Rhine graben and the Bohemian Massif.

The Miocene compressive episodes mostly affected the ToreMadeira Rise, the Gorringe and Ampère Banks, and the adjacent continental margins, as well as the Betic and Rif System on land. North of this deformation belt and up to the northern Bay of Biscay margin, hiatuses reveal Miocene movements (Site 398, Sibuet, Ryan, et al., 1979a) and a slight angular unconformity (Olivet et al., 1976; Groupe Galice, 1979).

\section{MORPHOLOGY OF THE SOUTHWEST GALICIA BANK CONTINENTAL MARGIN}

Detailed bathymetric Sea Beam surveys were performed on the western Iberian continental margin north of Cap Ortegal (Groupe Cybère, 1984), north (Groupe Transmarge, 1984) and east (this study) of Galicia Bank, on Vigo, Oporto, and Vasco da Gama Seamounts south of Galicia Bank (Mougenot et al., 1984), in Nazaré Canyon (Groupe Transmarge, 1982), and on Tore Seamount (J. L. Olivet, personal communication, 1985). These features were included in the bathymetric map by Lallemand et al. (1985a and b, Fig. 1), which provides a more precise morphologic depiction than does the Laughton et al. (1975) document.

The roughly north-south continental margin west of Iberia consists of two contrasting physiographic provinces north and south of $40^{\circ} \mathrm{N}$ latitude. Galicia Bank lies in the northern province, which also includes several other seamounts such as Vigo, Porto, and Vasco da Gama. The margin is separated from the narrow continental shelf by the Interior Basin, a large sedimentfilled depression, which trends generally north-south and stretches from the southern Bay of Biscay to Vigo Seamount. The seamounts may represent either horsts formed during the Early Cretaceous rifting episode (Laughton et al., 1975; Groupe Galice, 1979; Montadert et al., 1979d) or uplifted Eocene struc- 
tures (Boillot et al., 1979; Mougenot et al., 1984). South of $40^{\circ} \mathrm{N}$ latitude, large prominent canyons (Nazaré, Lisboa, Setubal, and Saõ Vicente Canyons) appear to be controlled by the late Hercynian fracture pattern (e.g., Boillot et al., 1974; Sibuet and Berthois, 1979).

The Seagal Sea Beam survey was restricted to the part of the continental margin south of Galicia Bank from the typical oceanic crust east of $13^{\circ} \mathrm{W}$ longitude to the first tilted fault block facing the Interior Basin at $11^{\circ} 25^{\prime} \mathrm{W}$ longitude (Figs. 1 and 4). The principal morphologic trends are the roughly north-south tilted fault block features, which correspond either to ridges (e.g., at $12^{\circ} \mathrm{W}$ longitude), to steep bathymetric gradients (e.g., at $12^{\circ} 12^{\prime} \mathrm{W}$ longitude), to a line of elongated seamounts (e.g., at $12^{\circ} 30^{\prime} \mathrm{W}$ longitude), or to a combination of steep gradients and elongated seamounts (e.g., at $12^{\circ} 50^{\prime} \mathrm{W}$ longitude). We interpret these features as having resulted from progressive westward burial below sediment of tilted north-south basement fault blocks.

Canyons can be traced continuously throughout the study area (Figs. 4, 8, and 9). A dendritic pattern with primary and secondary tributaries is observed on steep slopes between $11^{\circ} 40^{\prime}$ and $12^{\circ} 12^{\prime} \mathrm{W}$ longitude, whereas such canyons are absent or poorly defined when slope gradients decrease. The trends of the major canyons roughly follow the north-south basement structures and are bayonet-shaped where they pass through the north-south basement structures. The main canyons are fed from the north-south basement highs located on each of their sides (Fig. 9). ODP Site 641 is at the intersection of one main canyon and two tributaries just at the edge of the only observed depression in the area (Fig. 9). This depression, about $1 \mathrm{~km}$ in diameter and $20 \mathrm{~m}$ deep, is at a major slope break $\left(7^{\circ}\right.$ to $\left.2^{\circ}\right)$. Such depressions, called "splash pools" by Le Pichon and Renard (1982), are commonly observed on Sea Beam or Gloria records (Le Pichon and Renard, 1982; Kenyon et al., 1978) acquired on continental margins. Surveys made from a submersible of the Provence lower continental-slope canyons demonstrate that deep-water transport can carry large boulders, which tend to accumulate where the slope flattens out. Dams are thus built across the canyons, creating bathymetric depressions (Le Pichon and Renard, 1982). Slumped sediments, including Upper Cretaceous debris were recovered in the upper section of ODP Hole 641 (Site 641 chapter, this volume); ODP Site 641 is probably located on such a dam.

\section{STRUCTURE OF THE SOUTHWEST GALICIA BANK CONTINENTAL MARGIN}

The rift structures are illustrated by seismic profiles GP-11 and GP-12, which show a series of tilted fault blocks that delineate half grabens (Fig. 10). Normal faults bound the western side of these blocks. These structures on Galicia margin are even more impressive than the structure of two tilted fault blocks described south of the Meriadzek Terrace on the northern Bay of Biscay margin (Site 400, Montadert, Roberts, et al., 1979b). These latter two blocks display internal deformation and secondary faults, which fostered a debate about the estimated amount of extension (Le Pichon et al., 1983; Chenet et al., 1983).

One of the main results of ODP Leg 103 was to show that faulting and tilting occurred during several stages from very early Cretaceous to late Aptian (Boillot, Winterer, et al., 1985, 1986). The basement rock is composed of conglomerates with low-grade metamorphosed sedimentary rocks of possible Paleozoic age and altered volcanic rocks. Near Sites 638,639 , and 641 , the upper section of the tilted fault blocks includes Tithonian and Lower Cretaceous limestones, probably resting directly on the basement rock. Syn-rift deposits probably include Valanginian and Hauterivian turbidite sandstones and claystones overlain by Barremian to Aptian limestones, thin turbidites, and debris flows.
At Site 640 , located at the base of the margin, west of the previous sites, the upper section of a tilted fault block composed of Lower Cretaceous sandstones was drilled. This suggests that a second phase of rifting affected syn-rift deposits. Consequently, the 25-m.y.-long rifting, depending on the geometry of syn-rift deposits and on the position on the continental margin, affects both the pre-rift Jurassic and the syn-rift Lower Cretaceous deposits. In the following sections, we will refer to the surface lying at the top of both pre- and syn-rift sediments deformed during the different stages of the rifting phase as the rifting surface.

Figure 11 shows an interpretation of the composite multichannel seismic profiles GP-11 and GP-12 across the entire margin. Figure $11 \mathrm{~A}$ is a line drawing in two-way traveltime (in seconds). Figure 11B is a depth profile without vertical exaggeration drawn from the velocity-depth profile shown in Figure 7. $\mathrm{S} 1, \mathrm{~S} 2$, and S3 are the locations of the refraction profiles. The position of the Mohorovicić discontinuity is shown below the oceanic domain (S2) and the possibly thinned continental crust (S1).

The location of the seismic-transition zone (Fig. 11) was inferred from seismic-reflection and -refraction data, magnetic data, and ODP Site 637 results (see Site 637 chapter, this volume). The zone is probably located just west of Hill 5100 , where serpentinized peridotite were dredged (Boillot et al., 1980) and drilled (Boillot, Winterer et al., 1985, 1986).

The profile presented here can be considered as a typical section across a tilted fault-block margin. Rotated fault blocks are well expressed in the upper part of the margin. In contrast, in the lower part of the margin, extending east of the Hill 5100 for more than $30 \mathrm{~km}$, the top of the rifted series is highly irregular. Faulting and tilting in that region affect the Lower Cretaceous syn-rift sediments deposited during the early phases of rifting (ODP Site 640; Boillot, Winterer, et al., 1985, 1986). Below the syn-rift series, a strong reflector, named the $\mathrm{S}$ reflector (Figs. 10 and 11), shows undulations, which are mainly due to a pull-up effect below the tilted blocks. This reflector, however, is not strictly planar. The seismic velocity below the $\mathrm{S}$ reflector is about 6.1 $\mathrm{km} / \mathrm{s}$, and the Mohorov̌icić discontinuity is roughly $2 \mathrm{~km}$ below it. We shall discuss this later.

Figure 12 displays the Seagal east-west profiles in which only the topography of the top of the rifted series is shown. Profiles are represented in the east-west vertical plane without vertical exaggeration. The basement depth was calculated using the velocity-depth profile of Figure 7. The profile-to-profile correspondence of tilted fault blocks can easily be followed on the block diagram of Figure 12, which outlines the lateral extension of tilted fault blocks. The topographic map of the tilted fault blocks (Fig. 13) was established using all available seismic data (Fig. 3) and indicates the following:

1. The roughly north-south tilted fault blocks are continuous for as much as $60 \mathrm{~km}$.

2. A change of about $10^{\circ}$ in the direction of the crest and valley system is observed at $42^{\circ} 15^{\prime} \mathrm{N}$ latitude. As in the northern Bay of Biscay (Montadert et al., 1979d), a possibly transecting $\mathrm{N} 100^{\circ} \mathrm{E}$ fault does not show any lateral displacement. On the other hand, a slight slope change is observed along the strike of the features. A similar boundary also oriented $\mathrm{N} 100^{\circ} \mathrm{E}$ limits the southern part of Galicia Bank.

3. The tilted blocks and half-graben features dip southward about $3^{\circ}$ west of $12^{\circ} 15^{\prime} \mathrm{W}$ longitude and about $6^{\circ}$ east of this longitude and south of Galicia margin, as apparent in the seafloor morphology (Fig. 5).

4. The spacing between consecutive fault-block crests varies systematically between 9 and $18 \mathrm{~km}$ (Figs. 13 and 14). East of $12^{\circ} 15^{\prime} \mathrm{W}$ longitude, tilted fault blocks consist mostly of pre-rift 


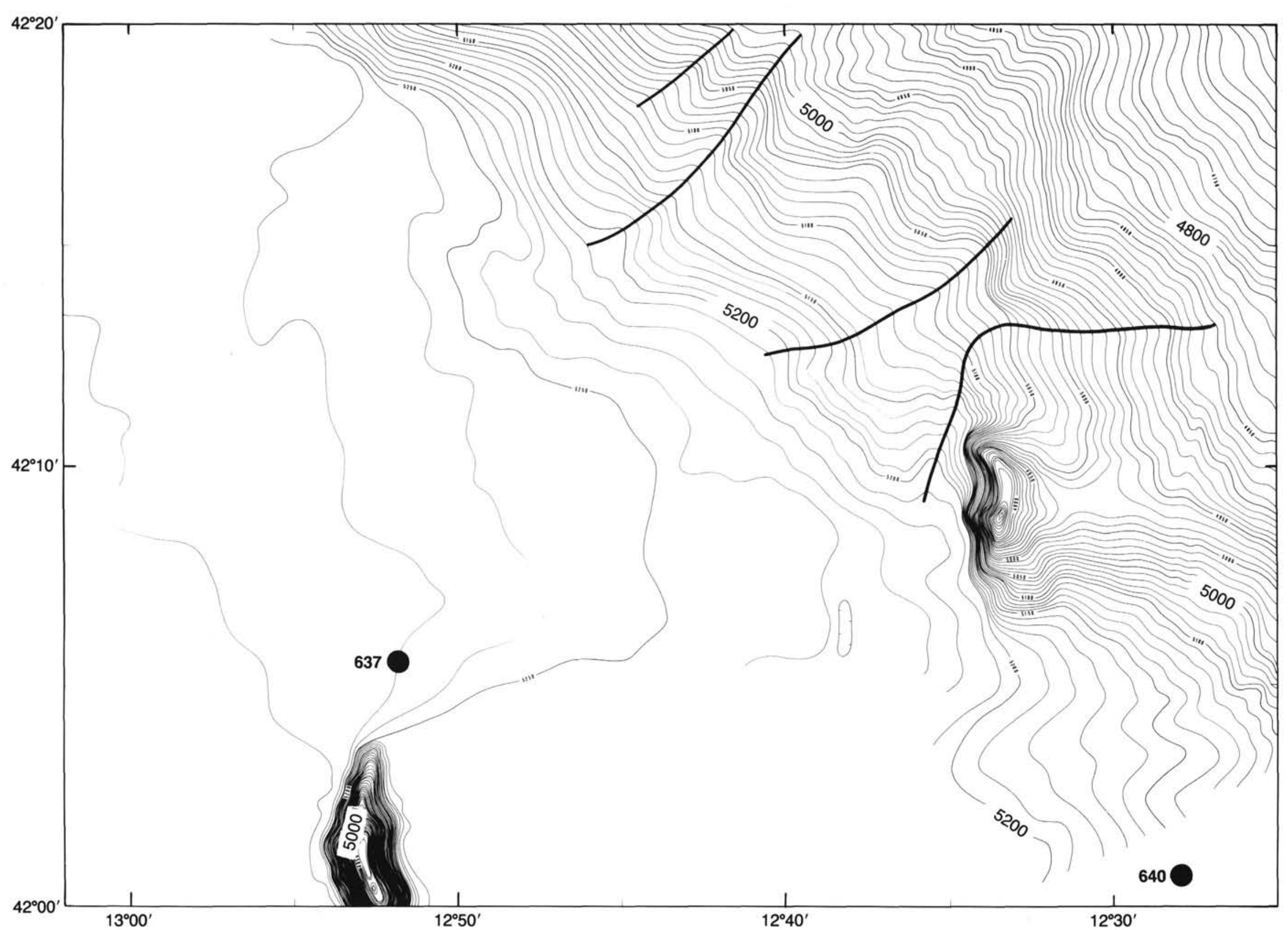




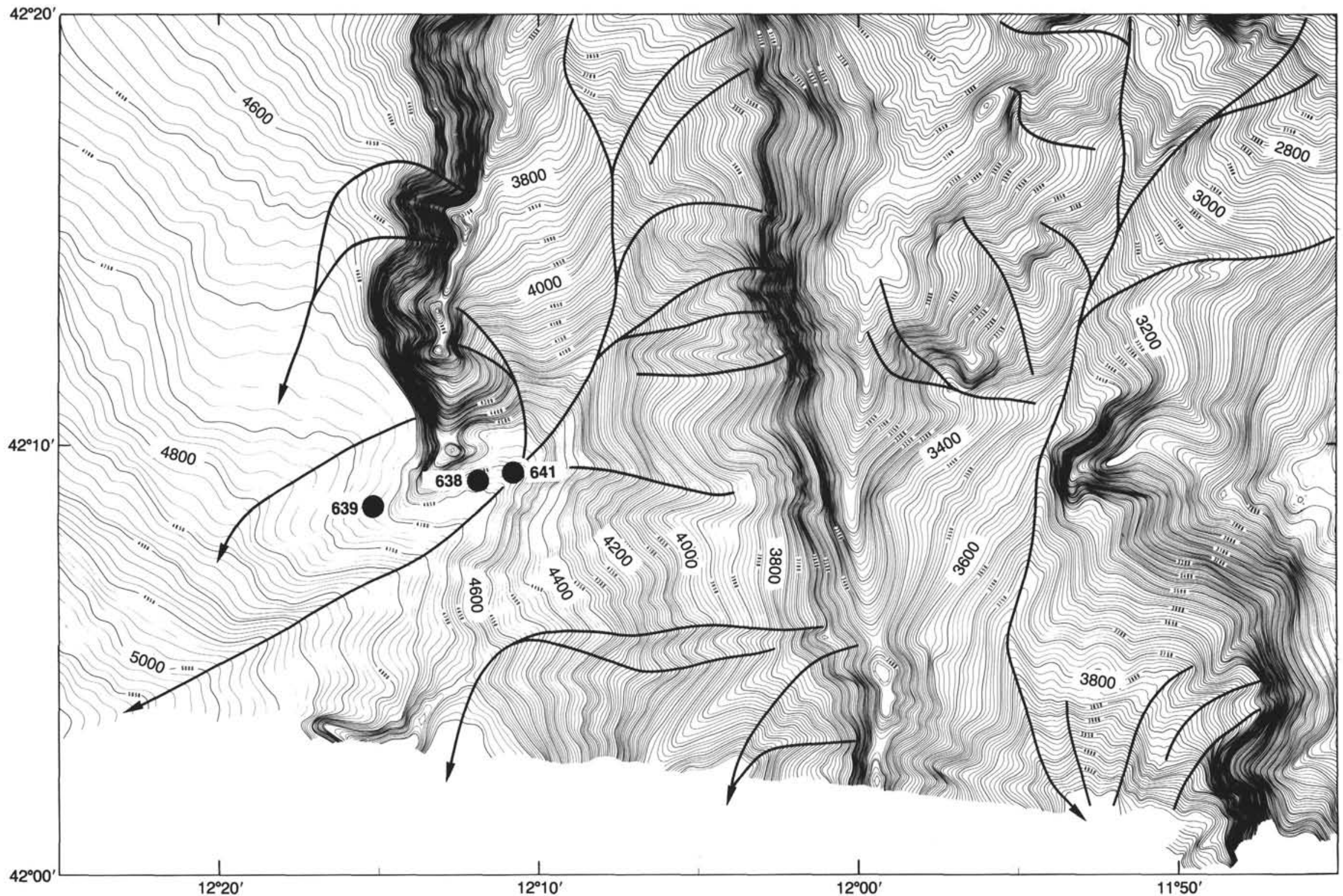

Figure 9. Detailed Sea Beam bathymetric map of the vicinity of ODP Sites 638,639 , and 641 drilled on the same tilted fault block. Contour spacing every $10 \mathrm{~m}$. Main canyons and tributaries are highlighted. 


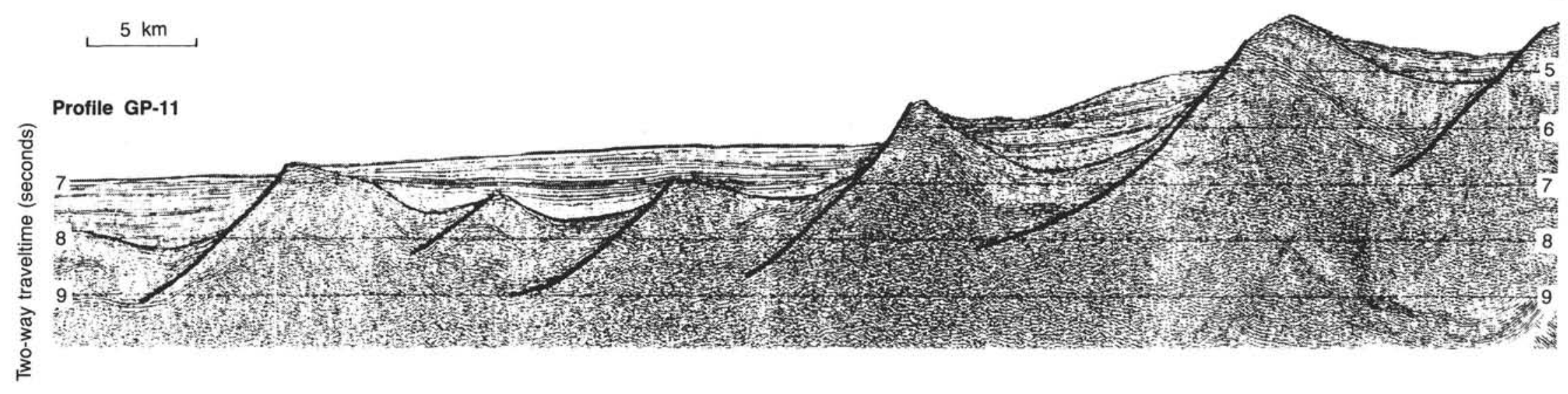

$6-$

$5 \mathrm{~km}$

$-6$

Profile GP-12

ST:

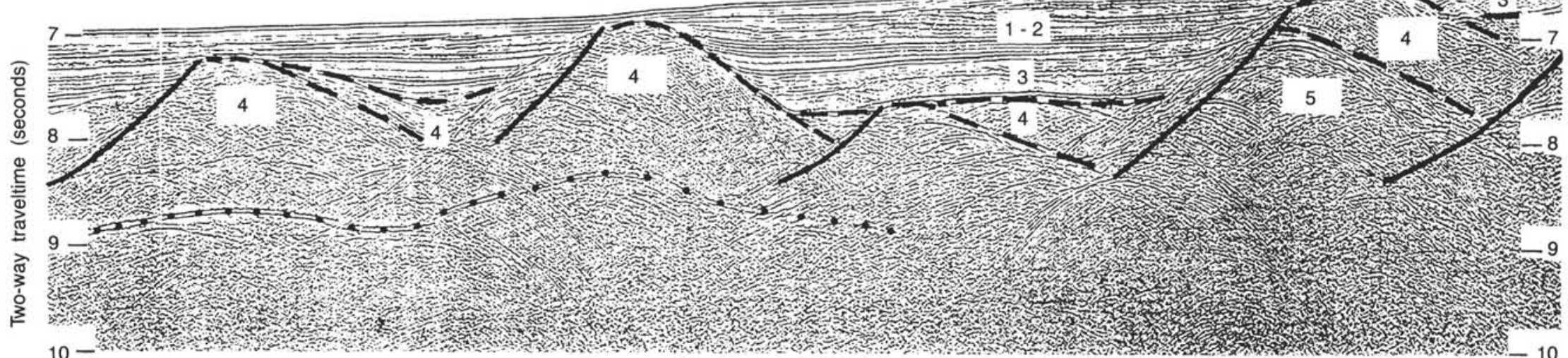

Figure 10. IFP-CNEXO multichannel seismic profiles GP-11 and GP-12 located in the upper and lower parts of Galicia margin (see Fig. 3 for profile locations). Migrated section in profile GP-11 is interpreted in terms of listric faults (after Montadert, 1982), but there is no seismic evidence for the curvature of the lower part of those faults. Profile GP-12 shows the S reflector (dotted line) below the syn-rift sediments affected by faulting and tilting during the latest phases of the Early Cretaceous rifting. Variation of traveltime shows a "pull-up" effect below the crest of the blocks, mainly owing to the difference in velocities within the blocks and sedi clude both pre- and syn-rift deposits, and the upper parts of the blocks consist of Valanginian syn-rift deposits, which were eroded during and after tilting: (1) Oligocene to Holocene; (2) Senonian to late Eocene; (3) early Albian to middle Cenomanian post-rift deposits; (4) Early Cretaceous syn-rift deposits involved or not in the tilting and faulting of blocks; (5) pre-rift sediments (Late Jurassic and older). 
A
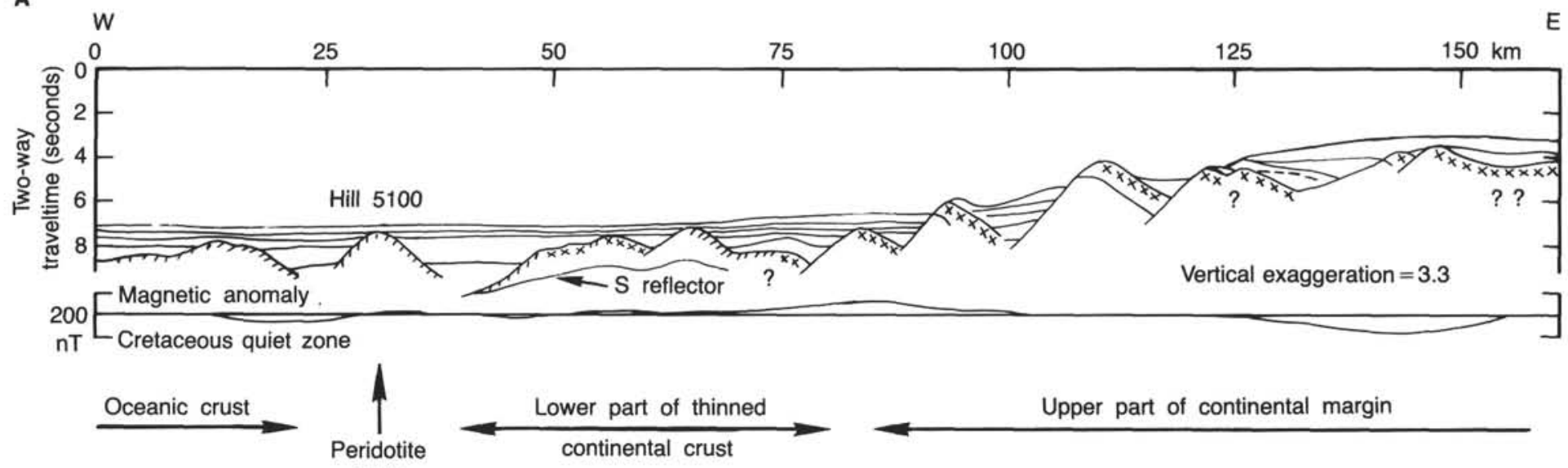

ridge

B

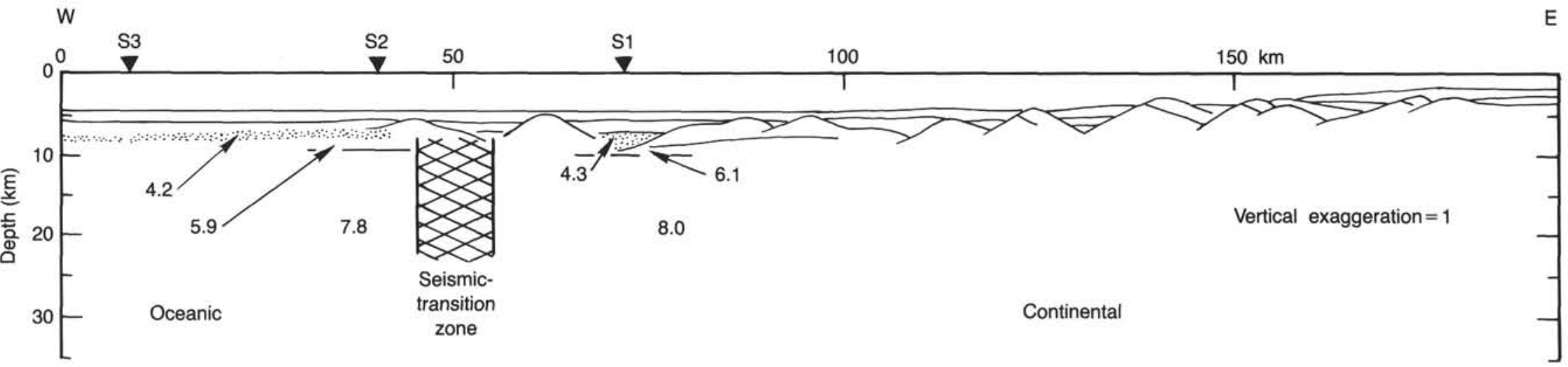

Figure 11. (A) Line drawing of the composite seismic profile GP-11 and GP-12, showing the three main regions of the continental margin (see text). (B) Distance-depth line drawing of the composite seismic profile GP-11 and GP-12 at the same horizontal scale as A. S1, S2, and S3 are the positions of refraction and wide-angle reflection profiles (Table 1). Velocities in km/s. 


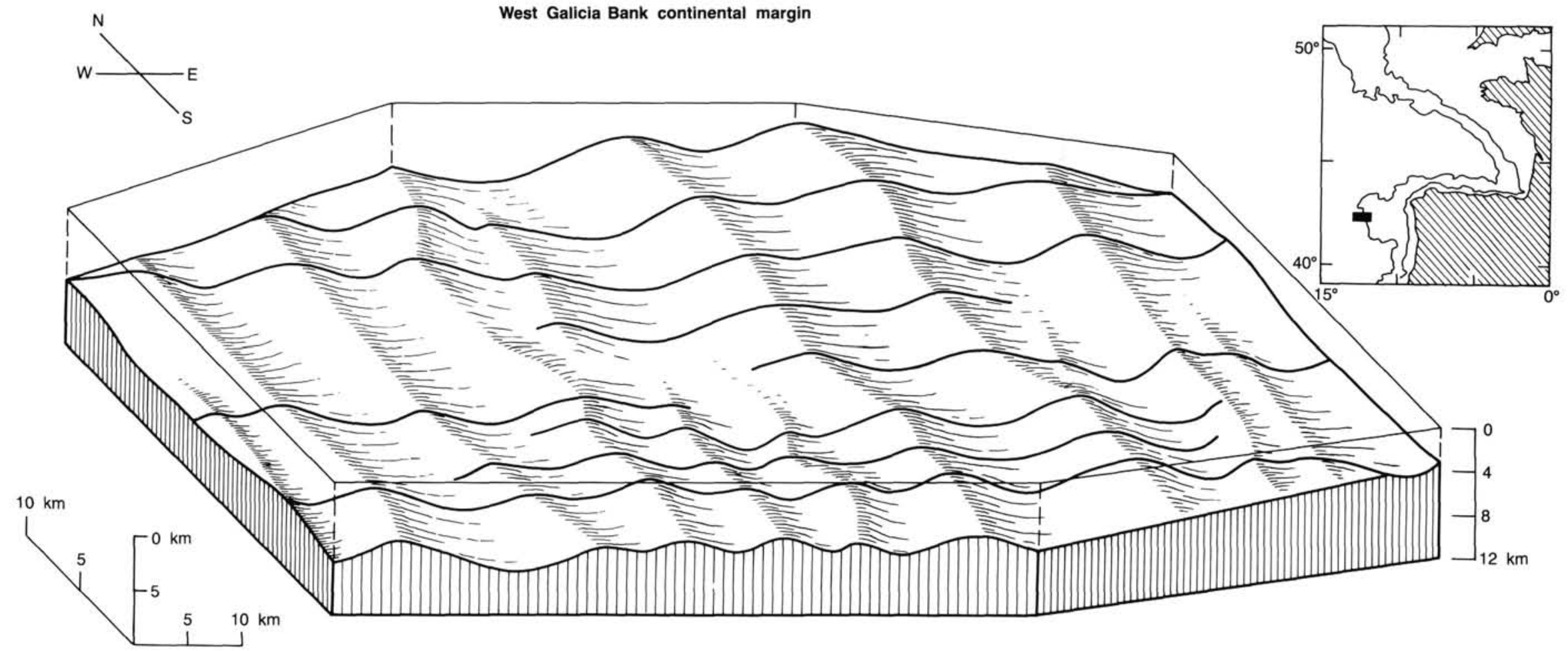

West Galicia Bank continental margin 


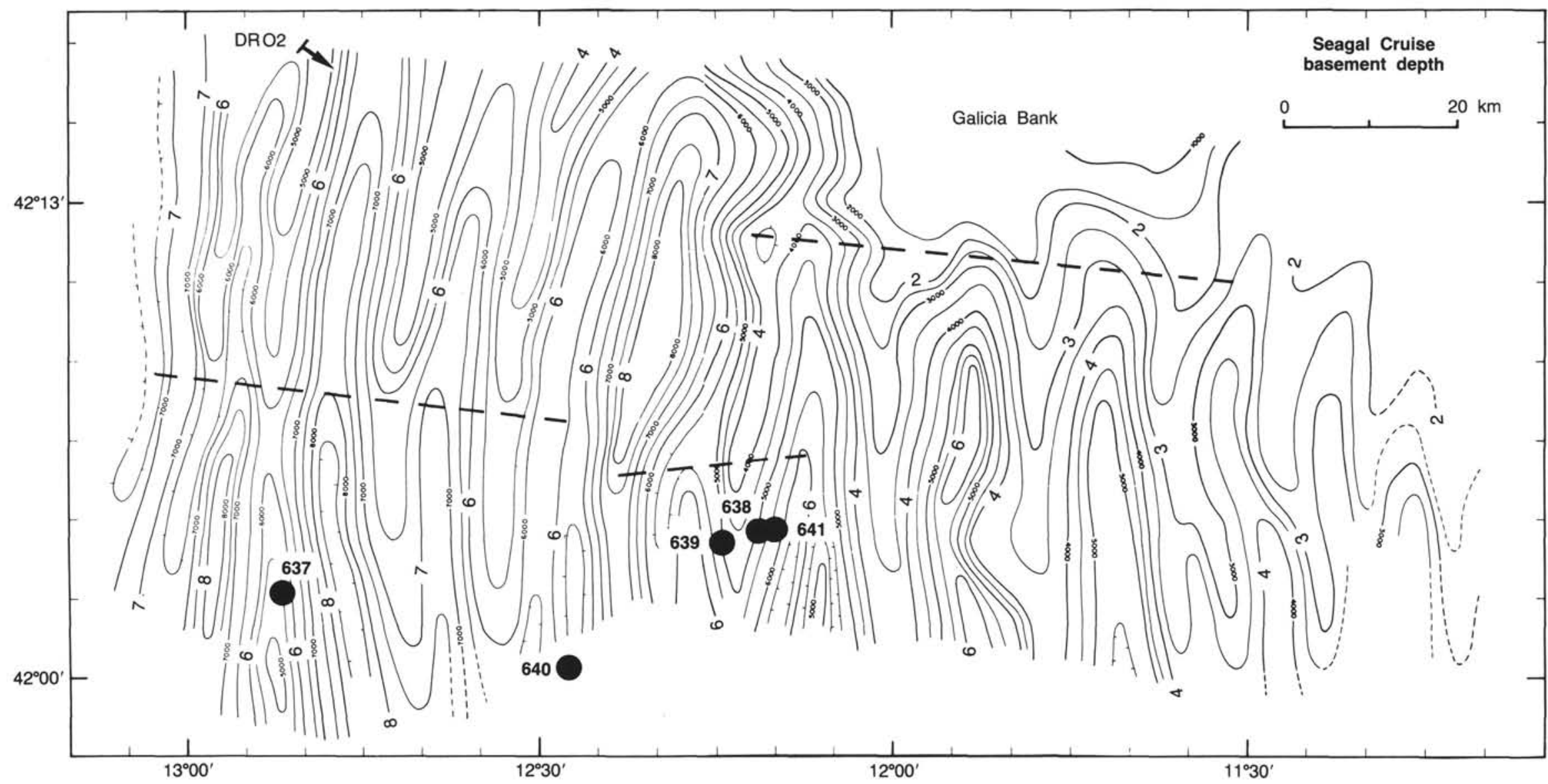

Figure 13. Topographic map of the surface of tilted faulted blocks in kilometers established from all available seismic data in Figure 3 . Isobath spacing is $0.5 \mathrm{~km}$ for ease of identification, they are labeled in both meters (smaller numbers) and kilometers (larger numbers). Sediment thicknesses were computed from the depth-velocity profile of Figure 7 . Dashed lines are possible transverse fault, southern edge of the Galicia Bank sensu stricto, and location of the slight $10^{\circ}$ change in the trend of tilted fault blocks. DR02 dredge and ODP Leg 103 drill sites are indicated. 


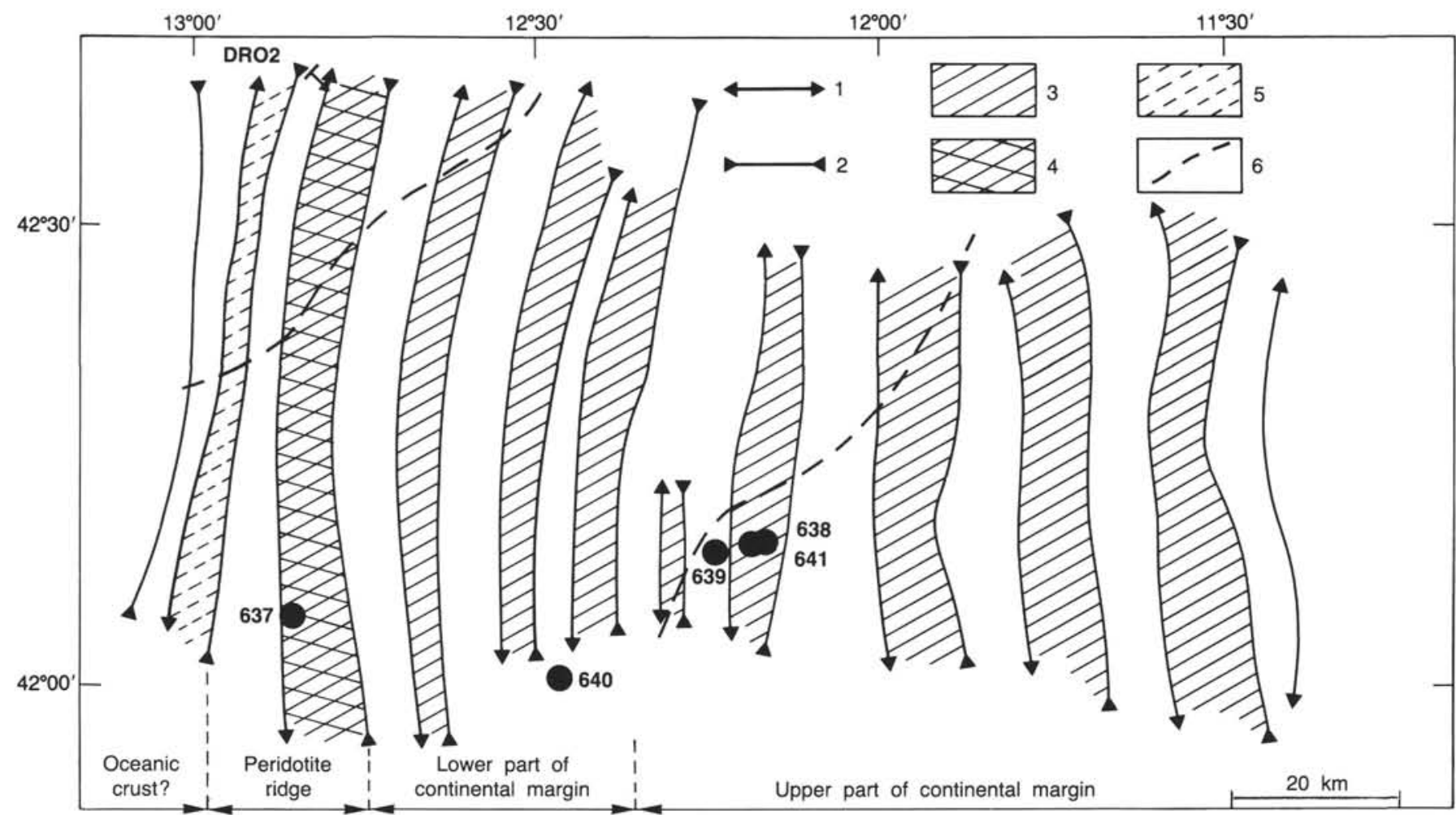

Figure 14. Distribution of crest and depression axes: (1) crests, (2) axes of half grabens or depressions, (3) subsiding part of tilted fault blocks. Blank areas correspond to the exposed part of normal faults along which tilted fault blocks glide, (4) eastern side of the peridotite ridge, (5) eastern side of oceanic ridges, (6) lower and upper parts of the continental margins, distinguished by the block spacing, the presence of the $\mathrm{S}$ reflector, and the magnetic data.

material and display a regular seaward increase in tilt. Their crest spacing is $13-18 \mathrm{~km}$. Between $12^{\circ} 15^{\prime} \mathrm{W}$ longitude and the serpentinized peridotite ridge, syn-rift deposits appear to constitute the main part of tilted fault blocks above the $\mathrm{S}$ reflector. Tilting is irregular, and crest spacing is only $9-13 \mathrm{~km}$.

To conclude, seismic data allow us to distinguish three main domains on southwestern Galicia margin:

1. East of $12^{\circ} 15^{\prime} \mathrm{W}$ longitude. The upper part of the margin is characterized by a series of tilted fault blocks, which include syn-rift deposits. ODP Sites 638, 639, and 641 were drilled here (see site chapters, this volume).

2. Between $12^{\circ} 15^{\prime} \mathrm{W}$ longitude and the peridotite ridge. The lower part of the margin is characterized by less well-defined tilted fault blocks created within syn-rift deposits. ODP Site 640 was drilled in this region (see Site 640 chapter, this volume).

3. The peridotite ridge and the probable oceanic domain west of the ridge. ODP Site 637 was drilled on this ridge (see Site 637 chapter, this volume).

Magnetic anomalies (Fig. 15) were mapped during the Jean Charcot survey. Diurnal variations were not removed. The map has an overall accuracy of about $\mathbf{3 0}$ gammas (nT), on the basis of intersections between tracks. Because the amplitudes of the anomalies are about $100 \mathrm{nT}$ peak to peak, this is a significant limitation to the accuracy of the contours and the trends. In the upper part of the margin, the morphology of the blocks is an obvious control on the trends of the linear anomalies. Quasicircular anomalies are superposed on these linear anomalies. In the lower part of the margin, the anomalies have a lower amplitude, which may be explained by the larger depth to basement (6 instead of $4 \mathrm{~km}$, resulting in a ratio of $1: 2$ for linear anomalies and 1:3 for point anomalies). However, the anomaly trends do seem to diverge from the block trends, and their wavelengths are significantly larger than the spacing between blocks. Finally, the edge of the oceanic domain is associated with a large anomaly, identified as the J anomaly (Sibuet and Ryan, 1979; Tucholke and Ludwig, 1982). Thus, the magnetic anomalies confirm the proposed subdivision of the margin into three domains.

\section{NATURE AND ORIGIN OF HILL 5100}

Several seismic profiles were obtained across the north-trending Hill 5100 and its north-south prolongation below the Iberian Abyssal Plain. ODP Site 637 recovered $74 \mathrm{~m}$ of serpentinized peridotite (see Site 637 chapter, this volume), confirming the previous results of dredging (Boillot et al., 1980). Figure 16 shows the Sea Beam bathymetric map and single-channel seismic data collected over this feature during the Seagal cruise. The feature acted as a dam, at least during the Cenozoic Period, which corresponds to the upper $0.7 \mathrm{~s}$ (two-way traveltime) of sediments. Although seismic profiles are extremely short, the interpretation of the large seismic coverage (e.g., profile GP-12, Fig. 16) calibrated at DSDP Site 398 (Groupe Galice, 1979) shows that horizons $\mathrm{A}$ and $\mathrm{B}$ correspond to main discontinuities linked to the compressive late Eocene and middle to late Miocene movements. At the contact of Hill 5100, an upward curvature of the reflectors increases downward and can be interpreted either as a 150$\mathrm{m}$ uplift of the ridge during the late Eocene or, more probably, as differential compaction on the flanks of the ridge (Fig. 16, profile GP-2).

About $50 \mathrm{~km}$ north of ODP Site 637, we recovered alkali basalt and serpentinized peridotite rocks in the same DR02 dredge station (from latitude $42^{\circ} 39.7^{\prime} \mathrm{N}$, longitude $12^{\circ} 50.0^{\prime} \mathrm{W}$ to latitude $42^{\circ} 38.9^{\prime} \mathrm{N}$, longitude $12^{\circ} 49.0^{\prime} \mathrm{W}$; from 4800 to $4500 \mathrm{~m}$ water depth). Dredged samples belong to outcrops because of the high tension ( 7 tons) recorded during the operation. The serpentinized peridotite is characterized by an abundance of chrysotile, antigorite, and olivine minerals. The chemical composition 


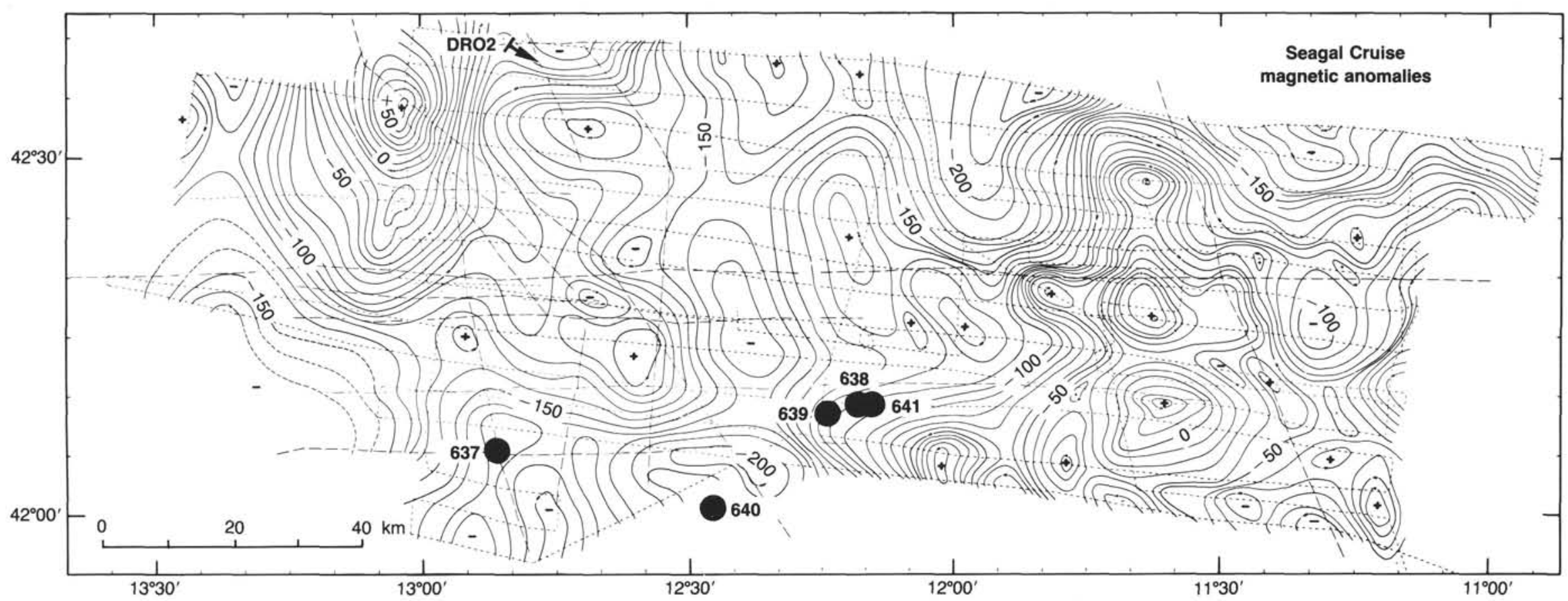

Figure 15. Magnetic anomalies in gammas (nT), established from Seagal data (dotted lines) and other available data (dashed lines). Contour interval, $10 \mathrm{nT}$. The upper and lower parts of the continental margin are distinguished by the change in the amplitude of magnetic anomalies. The peridotite feature (ODP Site 637) is marked only by a faint roughly north-south magnetic anomaly. The $\mathrm{J}$ anomaly corresponds to the large magnetic anomaly west of $13^{\circ} \mathrm{W}$ longitude. 


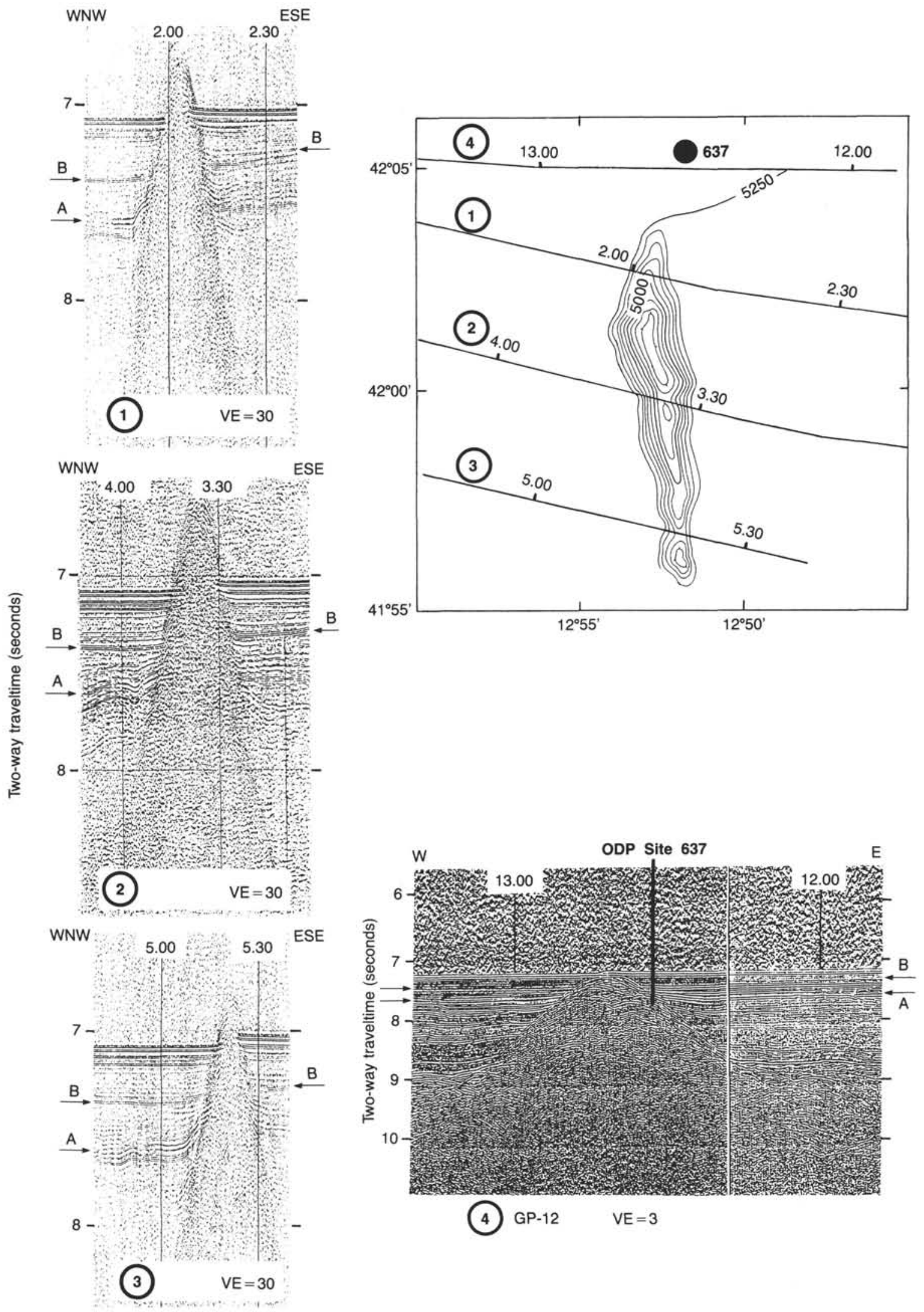

Figure 16. Bathymetric map of Hill 5100 established from Sea Beam data and seismic profiles over that feature. Isobath spacing is $50 \mathrm{~m}$. Location of single-channel seismic profiles 1, 2,3 (Seagal cruise), and 4 (IFP-CNEXO multichannel seismic profile GP12) shown on Sea Beam map. Late Eocene (A) and middle Miocene (B) unconformities are shown by arrows on the four seismic sections. 
characterized by high water $\left(23.3 \%\right.$ at $\left.1050^{\circ} \mathrm{C}\right) \mathrm{MgO}(20.2 \%)$ and $\mathrm{CaO}(19.4 \%)$ contents agrees well with the presence of these minerals. Dredge DR02 and ODP Site 637 belong to the same north-south basement ridge (Figs. 4 and 13). It is tempting to suggest that the peridotite ridge should extend northward along the base of western Galicia margin over a distance of about 100 km (Fig. 1). Nevertheless, we must note that the structural context differs considerably along this trend; the Hill 5100 basement feature seems to deepen northward and then to rise up again, becoming part of the lower steep continental slope west of Galicia Bank.

\section{DISCUSSION}

We previously noted that the lower margin blocks are mostly made of syn-rift sediments and apparently do not include "true" upper crust basement rock. This is similar to the situation at the base of the Armorican margin, where Barbier (1986), Barbier et al. (in press), and Le Pichon and Barbier (in press) reported that the lower blocks are made entirely of layered sediments and do not contain $6-\mathrm{km} / \mathrm{s}$ basement rock. They further showed that the restored vertical thickness of blocks systematically increases toward the continent.

Below the blocks, in the Armorican margin area, Barbier (1986) and Barbier and Le Pichon (in press) mapped the depth of a reflector at the base of the blocks that progressively increases toward the continent. Using the refraction results of Ginzburg et al. (1985) and their own wide-angle velocity determinations, they showed that the $6.5-\mathrm{km} / \mathrm{s}$ layer below the reflector lies immediately below $4.6-\mathrm{km} / \mathrm{s}$ layered sediments on the lower margin but below $6.0-\mathrm{km} / \mathrm{s}$ basement rock further inland. They consequently interpreted this reflector as being a tectonic discontinuity, cutting obliquely across the upper crust, its upper part being in direct contact with the lower crust.

In the Galicia area, the extent of the intermediate $\mathrm{S}$ reflector is much more limited, as it has been followed far below the upper part of the continental margin. Thus, we do not know whether we are dealing with the same type of reflector as that on the Armorican margin. The question then is does the $6-\mathrm{km} / \mathrm{s}$ layer below the S reflector consist of 2-km-thick lower crust material or does it consist of pre-rift platform carbonates or crystalline basement rock, as proposed by Boillot, Winterer, et al. (1985, 1986) and Meyer et al. (1985).

In either instance, the extreme thinning of the crust in the lower margin $(2 \mathrm{~km}$, exclusive of the syn-rift sediment thickness) clearly cannot be accounted for by the relatively modest stretching that affected the block layer itself (Le Pichon and Sibuet, 1981; Chenet et al., 1983). Note that, with such extreme thinning, local outcrop of serpentinized peridotite ridges across the remaining thin veil of crust is not unusual.

\section{CONCLUSIONS}

Data acquired during the Jean Charcot Seagal cruise allow us to establish a Sea Beam bathymetric map of the ODP Leg 103 drilling area and to compare the morphology with tilted blocks seen on single-channel and multichannel seismic profiles. Following are the main findings of this study:

1. North-south tilted fault blocks are continuous over distances of as much as $60 \mathrm{~km}$. They are spaced from 9 to $18 \mathrm{~km}$ apart.

2. The margin southwest of Galicia Bank can be divided into three main areas: (A) East of $12^{\circ} 15^{\prime} \mathrm{W}$ longitude, the upper part of the margin is characterized by a series of regularly tilted fault blocks 13-18 km apart, which include syn-rift deposits in their upper section. Magnetic anomalies appear to be partly controlled by basement faulting. (B) Between $12^{\circ} 15^{\prime} \mathrm{W}$ and Hill 5100 , the lower part of the margin is characterized by irregularly tilted fault blocks formed mainly of syn-rift deposits. The distance between blocks is only 9-13 km. The deep $\mathrm{S}$ reflector underlies this area. Magnetic anomalies have an orientation different from orientation of the blocks. (C) The oceanic domain is located west of Hill 5100 and is associated with the $\mathrm{J}$ anomaly.

\section{ACKNOWLEDGMENTS}

The authors express their gratitude to G. Boillot and E. Winterer, cochief scientists of Leg 103, who asked us to prepare this contribution for the Leg 103 Part A volume. Fruitful discussions with G. Boillot and J. L. Olivet are acknowledged. G. Auffret made the first description and analyses of the dredge DR02 samples. P. Miles and J. Gardner reviewed a draft of this paper and offered helpful suggestions. We thank the officers and crew of the Jean Charcot during the Seagal cruise, in particular Captain G. Girard. This is IFREMER contribution 66 .

\section{REFERENCES}

Arthaud, F., and Matte, P., 1975. Les décrochements tardi-hercyniens du Sud-Ouest de l'Europe. Géométrie et essai de reconstitution des conditions de la déformation. Tectonophysics, 25:139-171.

Avedik, F., and Howard, D., 1979. Preliminary results of a seismic refraction study in the Meriadzek-Trevelyan area, Bay of Biscay. In Montadert, L., Roberts, D. G., et al., Init. Repts. DSDP, 48: Washington (U.S. Govt. Printing Office), 1015-1023.

Baranyi, I., Lippolt, J. J., and Todt, W., 1976. Kalium-Argon Altersbestimmungen an Tertiärten Vulkaniten des Oberrhein-graben-Gebites: II. Die Alterstraverse vom Hegau nach Lothringe. Oberrheinische Geol. Abh., 35:41-62.

Barbier, F., 1986. Etude de la structure profonde de la marge Nord-Gascogne. implications sur la formation des marges passives [Thesis]. Université Pierre et Marie Curie, Paris.

Barbier, F., Le Pichon, X., and Duvergé, J., in press. Structure profonde de la marge Nord-Gascogne, implications sur le mécanisme de rifting et de formation de la marge continentale. Bull. Soc. Géol. Fr.

Bergerat, F., 1985. Déformations cassantes et champs de contraintes tertiaires dans la plateforme européenne [Thesis]. Université Pierre et Marie Curie, Paris.

Boillot, G., Auxiètre, J., Dunand, J., Dupeuble, P., and Mauffret, A., 1979. The northwestern Iberian margin: a Cretaceous passive margin deformed during Eocene. In Talwani, M., Hay, W., and Ryan, W. B. F. (Eds.), Deep Drilling Results in the Atlantic Ocean: Continental Margins and Paleoenvironment, $M$. Ewing Series 3: Washington D.C. (Am. Geophys. Union), 138-153.

Boillot, G., Dupeuble, P. A., Hennequin-Marchand, I., Lamboy, M., Leprêtre, J.-P., and Muselec, P., 1974. Le role des décrochements "tardi-hercyniens" dans l'évolution structurale de la marge continentale et dans la localisation des grands canyons sous-marins à l'Ouest et au Nord de la péninsule ibérique. Revue Géogr. Phys. Géol. Dyn., XVI(1):75-86.

Boillot, G., Grimaud, S., Mauffret, A., Mougenot, D., Kornprobst, J., Mergoil-Daniel, J., and Torrent, G., 1980. Ocean-continent transition off the Iberian margin: a serpentinite diapir west of Galicia Bank. Earth Planet. Sci. Lett., 48:23-34.

Boillot, G., Winterer, E., et al., 1985. Résultats préliminaires de la campagne 103 du JOIDES Resolution (Ocean Drilling Program) au large de la Galice (Espagne): sédimentation et distension pendant le "rifting" d'une marge stable-hypothèse d'une dénudation tectonique. Acad. Sci. Paris, C. R., 301:627-632.

Boillot, G., Winterer, E., et al., 1986. ODP Leg 103 drills into rift structures. Geotimes, 31(1):15-17.

Chenet, P.-Y., Montadert, L., Gairaud, H., and Roberts, D. G., 1983. Extension ratio measurements on the Galicia, Portugal and Northern Biscay continental margins: implications for evolutionary models of passive continental margins. In Watkins, J. S., and Drake, C. L. (Eds.), Studies in Continental Margin Geology. AAPG Mem., 34: 703-715.

de Charpal, O., Trémolières, P., Jean, F., and Masse, P., 1974. Un exemple de tectonique de plateforme, les causses majeurs. Inst. Fr. Pet. Rev., 29:715-732.

de Graciansky, P.-C., Poag, C. W., et al., 1985. Init. Repts. DSDP, 80: Washington (U. S. Govt. Printing Office).

Ginzburg, A., Whitmarsh, R. B., Roberts, D. G., Montadert, L., Camus, A., and Avedik, F., 1985. The deep seismic structure of the 
northern continental margin of the Bay of Biscay. Ann. Geophys., 3, 4:499-510.

Groupe Cybère (Malod, J.-A., Témine, D., Boillot, G., Capdevila, R., Cousin, M., Dupeuble, P.-A., Gonzalez-Ladeiro, F., Herbin, J.-P., Lamboy, M., Lepvrier, C., Martinez-Catalan, J., Mascle, G., Muller, C., Pastouret, L., Rojouan, F., Taugourdeau-Lantz, J., and Vanney, J.-R.), 1984. La marge déformée du Nord-Ouest de l'Espagne. Publ. du CNEXO, Résultats des Campagnes à la mer, 29.

Groupe Cymor (Pastouret, L., Auffret, G. A., Auzende, J.-M., Beuzart, P., Dubois, P., Séguret, M., Sigal, J., and Vanney, J.-R.), 1981. La marge continentale armoricaine, résultats d'observation en submersible et de dragages dans le canyon Shamrock. Acad. Sci., Paris, C. R., 292:741-748.

Groupe Galice (Auzende, J.-M., Jonquet, H., Olivet, J.-L., Sibuet, J.C., Auxiètre, J.-L., Boillot, G., Dunand, J.-P., Mauffret, A., de Charpal, O., Apotolescu, V., and Montadert, L.), 1979. The continental margin off Galicia and Portugal: acoustical stratigraphy, dredge stratigraphy, and structural evolution. In Sibuet, J.-C., Ryan, W. B. F., et al., Init. Repts. DSDP, 47, Pt. 2: Washington (U.S. Govt. Printing Office), 633-662.

Groupe Transmarge (Vanney, J.-R., Mougenot, D., Galisson, H., Gosselin, J., Hardonnière, C., Leuridan, J., Pigeon, P., Regnauld, H., El Robrini, M., Rojouan, F., Rothwell, G., and Virlogeux, P.), 1982. Levé bathymétrique de précision à l'aide du sondeur multifaisceaux Sea-Beam du canyon de Nazaré (marge continentale du Portugal). Acad. Sci. Paris, C. R., 294:1099-1102.

Groupe Transmarge (Vanney, J.-R., Mougenot, D., Galisson, H., Gosselin, J., Hardonnière, C., Leuridan, J., Pigeon, P., Regnauld, H., El Robrini, M., Rojouan, F., Rothwell, G., and Virlogeux, P.), 1984. Levé bathymétrique à l'aide du sondeur multifaisceaux "Sea-Beam" du versant septentrional du banc de Galice (marge continentale ouest ibérique). Acad. Sci. Paris, C. R., 299, II(3):115-120.

Guennoc, P., Jonquet, H., and Sibuet, J.-C., 1978. Carte magnétique de l'Atlantique nord-est. anomalies du champ total. Échelle 1/ 2400000. In CNEXO (Ed.), Paris (BRGM, Service Promotion et Vente).

Guennoc, P., Jonquet, H., and Sibuet, J.-C., 1979. Présentation d'une carte magnétique de l'Atlantique nord-est. Acad. Sci. Paris, C. R., 288(D):1011-1013.

Kamerling, P., 1979. The geology and hydrocarbon habitat of the Bristol Channel basin. J. Pet. Geol., 2:75-93.

Kenyon, N. H., Belderson, R. H., and Stride, A. H., 1978. Channels, canyons and slump folds on the continental slope between southwest Ireland and Spain. Oceanol. Acta, 1(3):369-380.

Lallemand, S., Mazé, J.-P., Monti, S., and Sibuet J.-C, 1985a, Présentation d'une carte bathymétrique de l'Atlantique Nord-Est. Acad. Sci. Paris, C. R., 300, II(4):145-149.

Lallemand, S., Mazé, J.-P., Monti, S., and Sibuet, J.-C., 1985b. Carte bathymétrique de l'Atlantique Nord-Est. Échelle 1/2400000. In CNEXO (Ed.) Paris (BRGM, Service Promotion et Vente).

Lallemand, S., and Sibuet, J.-C., in press. Tectonic implications of canyon directions over the northeast Atlantic continental margin. Tectonics.

Laughton, A. S., Roberts, D. G., and Graves, R., 1975. Bathymetry of the northeast Atlantic: Mid-Atlantic Ridge to southwest Europe. DeepSea Res. 22:791-810.

Le Pichon, X., Angelier, J., and Sibuet, J.-C., 1983. Subsidence and stretching. In Watkins, J. S., and Drake, C. L. (Eds.), Studies in Continental Margin Geology. AAPG Mem. 34:731-741.

Le Pichon, X., and Barbier, F., in press. Passive margin formation based on the Bay of Biscay study. Tectonophysics.

Le Pichon, X., Ewing, J., and Houtz, R., 1968. Deep-sea sediment velocity determination made while reflection profiling. J. Geophys. Res., 73:2597-2614.

Le Pichon, X., and Renard, V., 1982. Avalanching: a major process of erosion and transport in deep-sea canyons: evidence from submersible and multinarrow beam surveys. In Scrutton, R. A., and Talwani, M. (Eds.), The Ocean Floor: New York (Wiley), 113-128.

Le Pichon, X., and Sibuet, J.-C., 1971. Western extension of boundary between European and Iberian plates during the Pyrenean orogeny. Earth Planet. Sci. Lett., 12:83-88.

Le Pichon, X., and Sibuet, J.-C., 1981. Passive margins: a model of formation. J. Geophys. Res., 86:3708-3720.

Letouzey, J., and Trémolières, P., 1980. Paleo-stress fields around the Mediterranean since the Mesozoic derived from microtectonics: com- parison with plate tectonic data. Geologie des chaînes alpines issues de la Téthys. Mem. BRGM, 26th C.G.I., Paris, 115:261-273.

Masson, D. G., Montadert, L., and Scrutton, R. A., 1985. Regional geology of the Goban Spur continental margin. In de Graciansky, P.C., Poag, C. W., et al., Init. Repts. DSDP, 80, Pt. 2: Washington (U.S. Govt. Printing Office), 1115-1140.

Manspeizer, W., Puffer, J. H., and Cousminer, H. L., 1978. Separation of Morocco and eastern North America: a Triassic-Liassic stratigraphic record. Geol. Soc. Am. Bull., 89:901-920.

Meyer, A., Boillot, G., Winterer, E., et al., 1985. Early Cretaceous rifting and origin of the "S reflector" : preliminary results of Ocean Drilling Program Leg 103. Eos, 66(46):917 (Abstract).

Montadert, L., Roberts, D. G., et al., 1979a. Init. Repts. DSDP, 48: Washington (U.S. Govt. Printing Office).

Montadert, L., Roberts, D. G., et al., 1979b. Sites 399, 400, and Hole 400A. In Montadert, L., Roberts, D. G., et al., Init. Repts. DSDP, 48: Washington (U.S. Govt. Printing Office), 35-71.

Montadert, L., Roberts, D. G., et al., 1979c. Site 401. In Montadert, L., Roberts, D. G., et al., Init. Repts. DSDP, 48: Washington (U.S. Govt. Printing Office), 73-124.

Montadert, L., de Charpal, O., Roberts, D. G., Guennoc, P., and Sibuet, J.-C., 1979d. Northeast Atlantic passive continental margins: rifting and subsidence processes. In Talwani, M., Hay, W., and Ryan, W. B. F. (Eds.), Deep Drilling Results in the Atlantic Ocean: Continental Margins and Paleoenvironment, M. Ewing Series 3: Washington (Am. Geophy. Union), 154-186.

Montadert, L., 1982. Les marges continentales passives. La Recherche, $13: 730-742$.

Mougenot, D., Monteiro, J. H., Dupeuble, P.-A., and Malod, J.-A., 1979. La marge continentale sud-portugaise: évolution structurale et sédimentaire. Ciencias da Terra, 5: Lisboa (Univ. Nov. Lisboa), 223-246.

Mougenot, D., Kidd, R. B., Mauffret, A., Regnauld, H., Rothwell, R. G., and Vanney, J.-R., 1984. Geological interpretation of combined Sea Beam, gloria and seismic data from Porto and Vigo Seamounts, Iberian continental margin. Mar. Geophys. Res., 6:329-363.

Olivet, J.-L., Bonnin, J., and Auzende, J.-M., 1976. Manifestations des phases de compression tertiaire dans l'Atlantique du Nord-Est. 4th Réunion Sci. Terre, Paris, 311 (Abstract).

Olivet, J.-L., Bonnin, J., Beuzart, P., and Auzende, J.-M., 1984. Cinématique de l'Atlantique Nord et Central. Paris (Publications du CNEXO).

Parga, J.-R., 1969. Sistemas de fracturas tardihercinicas del macizo hesperico. Trabajos del Lab. Geol. de Lage, 37:1-15.

Pegrum, R. M., and Mountenay, N., 1978. Rift basins flanking North Atlantic Ocean and their relation to North Sea area. AAPG Bull., 62:419-441.

Réhault, J.-P., and Mauffret, A., 1979. Relationships between tectonics and sedimentation around the northwestern Iberian margin. In Sibuet, J.-C., Ryan, W. B. F., et al., Init. Repts. DSDP, 47, Pt. 2 : Washington (U.S. Govt. Printing Office), 663-681.

Renard, V., and Allenou, J.-P., 1979. Le Sea Beam, sondeur à multifaisceaux du N/O Jean Charcot: description, évaluation et premiers résultats. Rev. Hydrographique Internationale, Monaco, 56:35-71.

Roberts, D. G., Schnitker, et al., 1984. Init. Repts. DSDP, 81: Washington (U.S. Govt. Printing Office).

Savostin, L. A., Sibuet, J.-C., Zonenshain, L. P., Le Pichon, X., and Roulet, M.-J., 1986. Kinematic evolution of the Tethys Belt from the Atlantic Ocean to the Pamirs since the Triassic. Tectonophysics, 123: $1-35$.

Sibuet, J.-C., and Berthois, L., 1979. Dominant structural trends on the western continental margin of Iberia: implications of initial rifting. In Sibuet, J.-C., Ryan, W. B. F., et al., Init. Repts DSDP, 47, Pt. 2: Washington (U.S. Govt. Printing Office), 753-760.

Sibuet, J.-C., Ryan, W. B. F., et al., 1979a. Site 398. In Sibuet, J.-C., Ryan, W. B. F., et al., Init. Repts. DSDP, 47, Pt. 2: Washington (U.S. Govt. Printing Office), 25-233.

Sibuet, J.-C., Ryan, W. B. F., et al., 1979b. Init. Repts. DSDP, 47, Pt. 2: Washington (U.S. Govt. Printing Office).

Sibuet, J.-C., and Ryan, W. B. F., 1979. Site 398: evolution of the west Iberian passive continental margin in the framework of the early evolution of the North Atlantic Ocean. In Sibuet, J.-C., Ryan, W. B. F., et al., Init. Repts. DSDP, 47, Pt. 2: Washington (U.S. Govt. Printing Office), 761-775.

Sibuet, J.-C., Mathis, B., Pastouret, L., Auzende, J.-M., Foucher, J.-P., Hunter, P. M., Guennoc, P., de Graciansky, P.-C., Montadert, L., 
and Masson, D. G., 1985. Morphology and basement structures of the Goban Spur continental margin (northeastern Atlantic) and the role of the Pyrenean orogeny. In de Graciansky, P.-C., Poag, W., et al., Init. Repts. DSDP, 80: Washington (U.S. Govt. Printing Office), 1153-1165.

Tucholke, B. E., and Ludwig, W. J., 1982. Structure and origin of the J anomaly ridge, western North Atlantic Ocean. J. Geophys. Res., 87: 9389-9407.
Verhoef, J., Colette, B. J., Miles, P. R., Searle, R. C., Sibuet, J.-C., and Williams, C. A., 1986. Magnetic anomalies in the northeast Atlantic Ocean $\left(35^{\circ}-50^{\circ} \mathrm{N}\right)$. Mar. Geophys. Res, 8:1-25.

Ziegler, P. A., 1978. Northwestern Europe: tectonics and basin development. Geol. Mijnbouw, 57:589-626.

Ziegler, P. A., 1981. Evolution of sedimentary basins in northwest Europe. Petroleum Geology of the Continental Shelf of Northwest Europe: London (Institute of Petroleum), 9-39. 